RADOVI

UDK 904:688.932(497.523Varaždin)

Zavoda za znanstveni rad

Pregledni članak

HAZU Varaždin

Review

JERE DRPIĆ

Primljeno: 01. 02. 2019.

Novi Marof

Prihvaćeno: 07. 10. 2019.

drpic.jere@gmail.com

DOI: $10.21857 / 9 \times n 31$ crwoy

\title{
PREGLED ARHEOLOŠKIH ISTRAŽIVANJA POVIJESNE JEZGRE GRADA VARAŽDINA
}

U ovom radu donosi se sažeti presjek, tj. uvid u sva do sada dokumentirana arheološka istraživanja i nadzore, koji su se provodili u povijesnoj jezgri grada Varaždina. Taj prostor ukIjučuje utvrdu Stari grad i dio centra današnjeg grada, koji je bio omeđen fortifikacijskim sustavom (opkopima, bedemima i bastionima). Prema dokumentaciji Gradskog muzeja Varaždin prva zabilježena istraživanja (iskopavanja) su provedena 1938. god., dok se istraživanja intenziviraju od 90-ih godina, te ih je do danas provedeno mnogo, u različitom opsegu $i$ pozicijama na prostoru povijesne jezgre grada Varaždina. Rad je koncipiran tako da kronološki (podjela u tri vremenska perioda - prema intenzitetu provođenja arheoloških istraživanja), a zatim i prostorno (svaki lokalitet je pojedinačno tekstualno obrađen i na kraju skupno kartiran), sažeto prezentira sve najvažnije informacije ${ }^{1}$, tj. okolnosti istraživanja svakog arheološki dokumentiranog položaja u gradu, s najvažnijim pokretnim i nepokretnim nalazima. ${ }^{2}$ Time su na jednom mjestu objedinjena sva dosadašnja istraživanja unutar gradske jezgre Varaždina. Revizija je to dosad obavljenog arheološkog rada te doprinos valorizaciji arheološke baštine grada Varaždina.

Razlog je ograničenosti teksta članka veliki obujam istraživanja.

2 Rad se uglavnom oslanja na dokumentaciju Arheološkog odjela Gradskog muzeja Varaždin, tj. izvještaje o istraživanjima u gradu Varaždinu. 


\section{UVOD}

Povijesna jezgra grada Varaždina cjelina je koja obuhvaća nekadašnji utvrđeni grad: utvrdu Stari grad i tzv. unutarnji grad (civitas interior) sa širokim potezima opkopa i bedema oko njih (koji su od sredine 19. st. sustavno urbanizirani ${ }^{3}$ ), te obilaznu srednjovjekovnu prometnicu, tzv. Via fossata ambiens. ${ }^{4}$ Premda kroz svoju povijest jako važna prometna, upravna i kulturna točka sjeverozapadne Hrvatske, Varaždin, niti njegova utvrda Stari grad, kroz raniju povijest arheoloških istraživanja u sjeverozapadnoj Hrvatskoj nisu bili predmet sustavnog interesa arheologa. ${ }^{5}$ Razloge zašto je tome tako treba možda tražiti u činjenici da su se arheolozi u prošlosti uglavnom koncentrirali na neke druge značajne arheološke lokalitete, datirane uglavnom u prapovijesna razdoblja i antiku, a kakvima širi prostor oko grada Varaždina zaista obiluje. ${ }^{6}$ Ti su lokaliteti danas uglavnom nenaseljeni te ih je, naravno, zbog toga bilo i lakše istraživati. ${ }^{7} \mathrm{~S}$ druge strane urbana ${ }^{8}$, a posebice novovjekovna arheologija ${ }^{9}$ općenito se intenzivnije razvijaju u Hrvatskoj tek posljednjih 30-ak godina. Kako se najintenzivniji razvoj grada Varaždina vezuje upravo za razdoblje srednjeg i novog vijeka, i to u ovom slučaju u urbanoj cjelini, razumljivo je zašto se ranije nisu ustalila arheološka istraživanja u urbanoj jezgri Varaždina. Naravno, ovo ne znači da do prije 30-ak godina nisu izvedena nikakva arheološka istraživanja u samom gradu, već samo da su ona bila sporadična i smanjenog opsega. Kad smo sagledali ove činjenice, sljedeći korak je podijeliti to razdoblje povijesti arheoloških istraživanja u Varaždinu upravo prema inten-

\footnotetext{
Navedeno se prvenstveno odnosi na opkope i bedeme unutarnjeg grada.

http://www.min-kulture.hr-(Registar kulturnih dobara), preuzeto 28. prosinca 2018.

5 Situacija s razvojem gradske arheologije u Varaždinu usporediva je $\mathrm{s}$ onom urbane cjeline grada Zagreba. Vidi na: (http://www.mgz.hr/hr/izlozbe/U\%20slu\%C5\%BEbi\%20arheologije,474.html), preuzeto 28. prosinca 2018. Vidi i u: Aleksandra BUGAR, Boris MAŠIĆ, „U službi arheologije, Gospođa NN iz 13. stoljeća", Zagreb moj grad 7, 44, Zagreb, 2013., 86. - 87.

6 Vidi u: Skupina autora, Registar arheoloških nalaza i nalazišta sjeverozapadne Hrvatska, Muzejsko društvo sjeverozapadne Hrvatske-sekcija arheologa i preparatora, Bjelovar, 1997., 95. - 144.

7 Kao primjer možemo istaknuti značajnog arheologa Stjepana Vukovića koji je gotovo čitav svoj znanstveni vijek posvetio višeslojnom lokalitetu; špilji Vindiji.

8 Izuzeci su jedino urbane cjeline na jadranskoj obali s antičkim kulturnim slojem, koje su jako rano u odnosu na, primjerice, one u sjeverozapadnoj Hrvatskoj pobudile interes arheologa, a time posredno i bile temelj početku urbane arheologije u Hrvatskoj. Jedan od primjera takve urbane cjeline na jadranskoj obali je Pula, čija jezgra se istražuje već od početka 19. st. Vidi u: Matijašić, R., „Urbana arheologija u Puli", Histria Antiqua 1/1995, Pula, 1995., 37. - 46.

9 „Tek 2009. godine u znanstvenu klasifikaciju humanističkih znanosti u polje arheologije uvedena je nova grana; novovjekovna arheologija“ Vidi u: Ana AZINOVIĆ BEBEK, „Novovjekovna arheologija u Hrvatskoj - Problemi metodologije, terminologije i imena“, Prilozi Instituta za arheologiju u Zagrebu, 35/2018, Zagreb, 2018., 302.
} 
zitetu arheoloških istraživanja. Nametnula se podjela u tri osnovna razdoblja: prvo razdoblje, koje je trajalo do Drugog svjetskog rata (Filićevo razdoblje); drugo razdoblje, nakon Drugog svjetskog rata i treće razdoblje nakon 1993. god. Okolnosti ovih razdoblja donose se u nastavku teksta, ali usputno i sva arheološka istraživanja koja su provedena u pojedinom razdoblju, kronološkim slijedom.

\section{RAZDOBLJE DO DRUGOG SVJETSKOG RATA (FILIĆEVO RAZDOBLJE) ${ }^{10}$}

Kronološki gledano, prvi spomen nekog iskopavanja u užoj jezgri grada Varaždina, a koje bi se eventualno moglo povezati s istraživanjem, odnosi se na prostor utvrde Stari grad iz 1938. god. Tada su prilikom kopanja bunara u istočnom dijelu unutarnjeg dvorišta utvrde nađeni, prema navodima prof. Krešimira Filića, „nekakvi zidovi“. ${ }^{11}$ Nažalost, o tim istraživanjima nemamo nikakvih arheoloških tragova ni druge vezane dokumentacije. Već 1941. god. iskopava se ponovno, i to na prostoru južno od vanjskog dvorišta ispred Starog grada, a u svrhu preuređenja tog prostora u park. Tom prigodom otkrivena je ulazna kula u vanjsko dvorište utvrde. Filić spominje da se kod kopanja u tom dijelu dvorišta naišlo na temelj ulazne kule za to vanjsko dvorište. Također spominje da je kula imala dvije građevinske faze. Navodi da je u starijoj fazi bila nešto manjih dimenzija, a u mlađoj prostranija. Dalje kaže da je ova kula porušena početkom 19. st. jer je prijetila urušavanjem zbog nepovezanosti s gradskim zidom i uslijed djelovanja vode iz opkopa. Nažalost, ova iskopavanja nisu metodološki obavljena pa imamo jako malo podataka o tom iskopavanju. Nakon što je iskopana, ova kula je ponovno zatrpana. O ovome svjedoči samo par fotografija koje su izrađene u listopadu 1941. god. te prepiska Varaždinskog muzealnog društva s Gradskim poglavarstvom u Varaždinu od 11. ožujka 1942. o uređenju okolice Starog grada, iz koje saznajemo da se 1938. god., citiram: „Markiralo i opkop s Padovčeva trga...", tj. iskopavalo taj opkop. Iz tog izvora je nejasno je li upravo tom prigodom pronađeno ranosrednjovjekovno koplje s krilcima, koje se datira u početak 9. st., a koje se danas čuva na AO GMV-a, jer Krešimir Filić ne spominje izričito taj nalaz. ${ }^{12}$

10 Profesor Krešimir Filić, iako nije bio arheolog po struci, kao ravnatelj Gradskog muzeja Varaždin poduzeo je više iskopavanja unutar prostora utvrde Stari grad i to prilikom radova na uređenju same utvrde i prostora oko nje. Kratki opis ovih radova objavljen je i u publikaciji Varaždinski muzej 1943. god. u spomen 20-te godišnjice postojanja „Varaždinskog muzealnog društva“. Vidi u: Krešimir FILIĆ, Varaždinski muzej, u spomen 20-godišnjice postojanja "Varaždinskog muzealnog društva", izdanja "Varaždinskog muzealnoga društva" broj 2, 1943., 16., 17.

11 K. FILIĆ, Varaždinski muzej, 1943., 16., 17.; Spomenka TEŽAK, Marina ŠIMEK, Tomislav LIPLJIN, „Županija varaždinska u srednjem vijeku“, Katalog izložbe Gradskog muzeja Varaždin, Varaždin, 1999., 25., 36.; fotodokumentacija Arheološkog odjela Gradskog muzeja Varaždin (dalje kratica AO GMV).

12 Državni arhiv u Varaždinu, opći spisi 1942., kat. 44, br. 4173.; Vidi i u: K. FILIĆ, Varaždinski muzej, 1943., 27; dokumentacija PO GMV-a. 


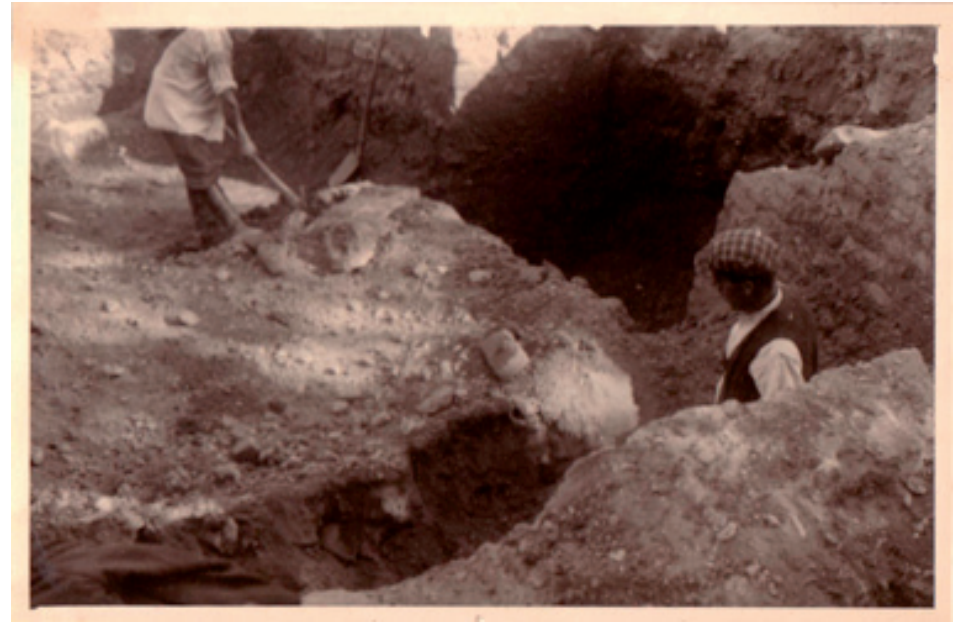

Slika 1. Fotografija u tijeku iskopa dvorišne kule Izvor: fotodokumentacija GMV-a

lako slučajan, ovaj nalaz s nepotpunim arheološkim kontekstom predstavlja jako bitnu kariku u povijesti Varaždina jer je zasada najstariji nalaz nađen na prostoru ranije jezgre grada Varaždina, tj. utvrde Stari grad. Indikativno je također da je ovo oružje pronađeno uz fortifikacijski objekt.

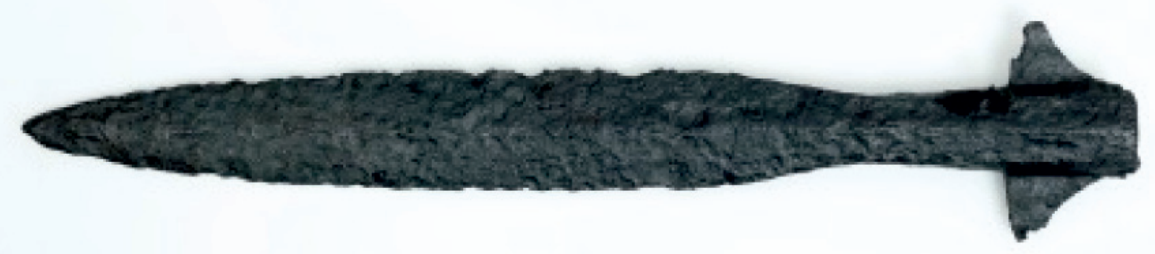

Slika 2. Fotografija franačkog koplja s krilcima iz GMV, inv. br. GMV AO 4473

(Snimio: Andrej Švoger) 


\section{RAZDOBLJE NAKON DRUGOG SVJETSKOG RATA}

Na prva prava arheološka istraživanja na prostoru urbane jezgre Varaždina čekalo se do 1954. god. Te godine, Stjepan Vuković, ${ }^{13}$ tadašnji kustos Prahistorijskog odjela Gradskog muzeja Varaždin provodi arheološka istraživanja zaštitnog karaktera na trasi izgradnje kanalizacije na današnjem Franjevačkom trgu, tadašnjem Adžijinom. Prilikom iskopa nedaleko od palače Hercer naišlo se na ukopani drveni objekt. Na zamolbu muzealaca, tadašnji Odjel za komunalne poslove iz Varaždina preuzima na sebe posao iskopa, impregniranja i konzerviranja brvnare, dok Stjepan Vuković metodološki istražuje te prikuplja i dokumentira nalaze. Prilikom istraživanja primijenio je metodu iskopavanja kvadratnom mrežom kakvu je koristio i prilikom istraživanja špilje Vindija. Ovakvim pristupom dobio je jako precizan prostorni raspored svih pokretnih i nepokretnih nalaza te stratigrafiju lokaliteta. ${ }^{14}$

Istraživani drveni izduženi objekt (tzv. Brvnara) bio je postavljen u smjeru istok-zapad. Sačuvani dio brvnare bio je dimenzija $7 \mathrm{~m} \times 4 \mathrm{~m}$, a do visine od 1,3 m. Temelj ovog objekta bio je ukopan u dravski šljunak i to 4,8 m u odnosu na današnju razinu hodne površine trga. Upravo zbog toga Stjepan Vuković naglašava poteškoće prilikom istraživanja jer je voda konstantno nadirala u sondu. Unatoč tomu, zabilježio je osam stratigrafskih jedinica, od kojih su 3., 4., 6. i 7. sadržavale arheološki materijal. Također u trasi iskopa za kanalizaciju pronađeni su još i bunar te korito potoka (smjera pružanja S-J). Bunar je bio na samo $35 \mathrm{~cm}$ dubine u odnosu na današnju razinu trga. Unutar drvenog objekta nađen je i raznovrstan pokretni arheološki materijal. Primjerice, fragmenti keramičkog i staklenog posuđa, pećnjaci te veća količina metalnih predmeta; razni čavli, šila, potkove, okovi, dijelovi brava, nosač mača, ostruge. Analizom ostataka drva, 1982. god.,

13 Ovo je bio prvi metodološki istražen arheološki lokalitet unutar jezgre grada Varaždina, koja je bila jako dugo zanemarena i nije bila u fokusu arheologa i konzervatora. lako možda čak i nesvjesno, time je Stjepan Vuković udario temelje gradske i novovjekovne arheologije u Varaždinu.

14 Arheološka dokumentacija ovih istraživanja sastoji se od dnevnika iskopavanja, crteža, popisa predmeta te fotografija lokaliteta; dokumentacija AO GMV-a (Varaždin-Brvnara, 1954.). Istraživanja su predstavljena javnosti već 1954. god. u Varaždinskim vijestima u broju 429. i 430., pod naslovom "Komunalni radovi napreduju" i "Stara brvnara iz davnih vremena". Vidi na: (http://library.foi.hr/ novine/), preuzeto 10. studenoga 2018. Ova istraživanja je obradila i Jasna Tomičić u članku: Jasna TOMIČıć, "Varaždinska brvnara", Muzejski vjesnik br. 6, 1983., 55. - 57., a zatim se temom bavila i Marina Šimek, u dva članka: Marina ŠIMEK, "Dvije ostruge kasnog srednjeg vijeka iz Varaždina”, Opvscula archaeologica 23-24, 1999. - 2000., 347. - 351.; Marina ŠIMEK, "Srednjovjekovno staklo iz Varaždina", Archaeologia Adriatica IV, 2010., 307.; a dio teksta o ovom istraživanju je posvetila i u katalogu izložbe Gradskog muzeja Varaždin - Županija varaždinska u srednjem vijeku; Vidi u: M. ŠıMEK i dr., Županija varaždinska u srednjem vijeku, 1999., 36. 
dobiveni su rezultati koji datiraju drvo u 1435. +/- 50 godina. Daljnjom obradom pokretnih nalaza uvidjelo se da većina nalaza odgovara upravo razdoblju od 15 . do 16 . stoljeća. ${ }^{15}$

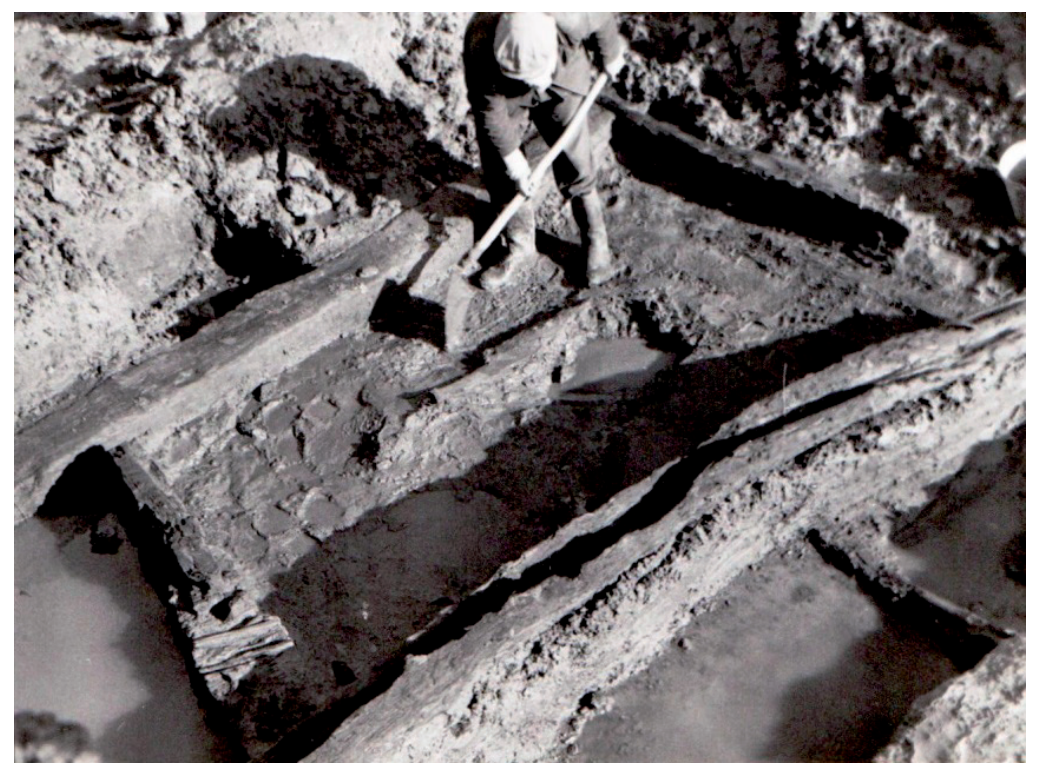

Slika 3. Fotografija tokom iskopa 1954. god., tzv. Brvnare na današnjem Franjevačkom trgu, Izvor: fotodokumentacija AO GMV-a

Nakon ovog pozitivnog primjera zaštitnog istraživanja, nažalost nije se razvio kontinuitet u arheološkom nadzoru i istraživanju uže gradske jezgre, već se tek tu i tamo kroz dokumentaciju AO GMV-a spominje neko iskopavanje u gradu, a koje su kustosi Arheološkog odjela uglavnom uspjeli popratiti jedino fotoaparatom i eventualno kojom skicom. Jednom prilikom je tako Stjepan Vuković 1960. god. zabilježio u svom terenskom dnevniku nalaz u Ulici A. Kačića Miošića ispred kućnog broja 4. Na skici su, unutar trase vodovoda koji prolazi sredinom ceste, vidljiva ucrtana dva drvena pilota od hrastovine s dimenzijama: lijevi pilot $52 \mathrm{~cm}$ promjera, desni pilot $55 \mathrm{~cm}$ promjera, a bili su udaljeni jedan od drugoga $4 \mathrm{~m}^{16}$

15 Isto.

16 Dokumentacija AO GMV-a, Terenski dnevnik Stjepana Vukovića. Treba napomenuti da prema planovima grada možemo pretpostaviti da je na približnom mjestu ovog nalaza prolazio zapadni gradski zid u smjeru sjever-jug, duž današnje istočne strane UI. Ivana Cankara. Vidi u: Mirela SLUKAN ALTIĆ, Povijesni atlas gradova V. svezak Varaždin, 2009., 118. - 128. 


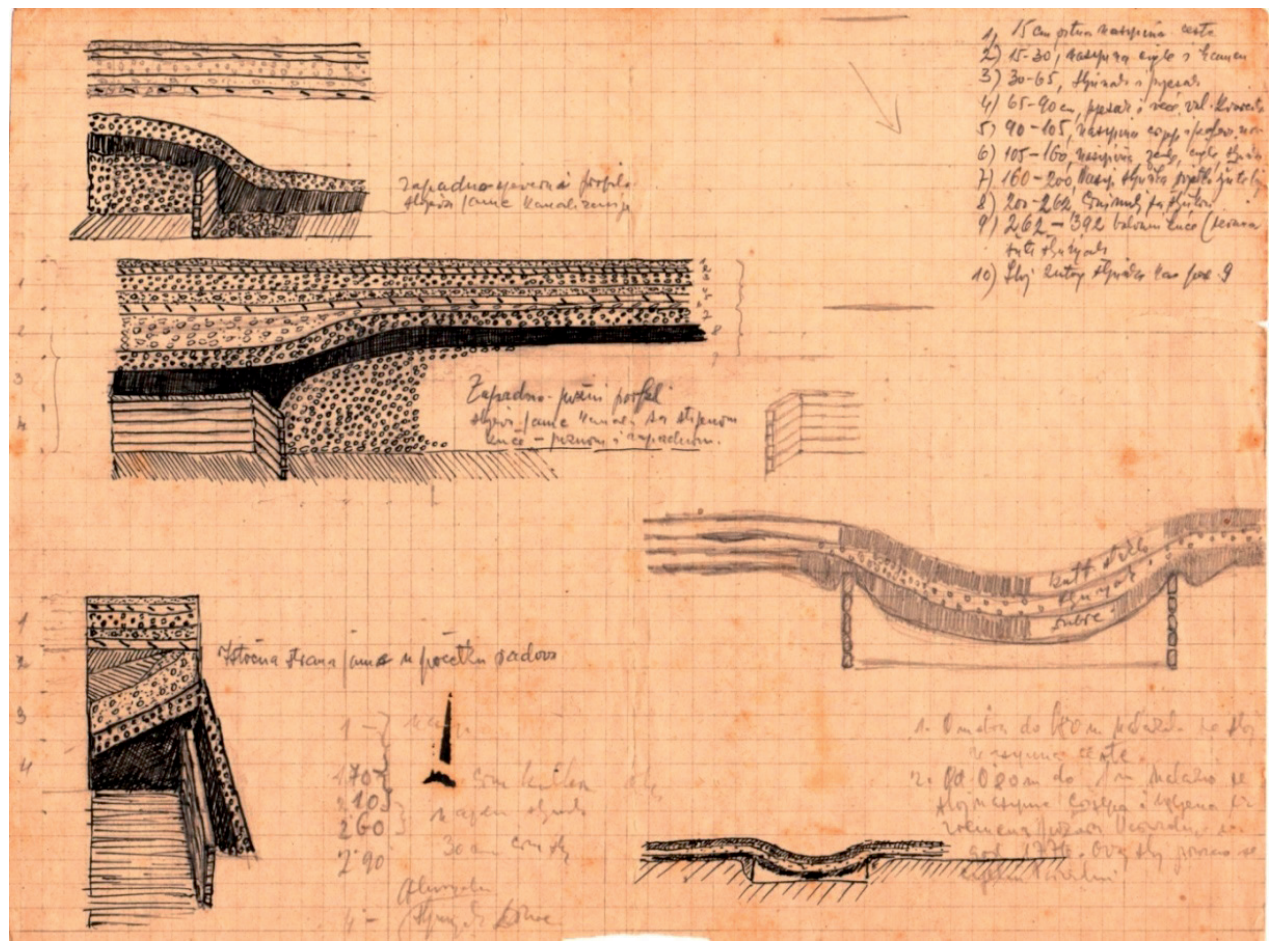

Slika 4. Sken stranice terenskog dnevnika Stjepana Vukovića s crtežima nastalim prilikom iskopa tzv. Brvnare, izvor: Terenski dnevnik Stjepana Vukovića, dokumentacija AO GMV-a

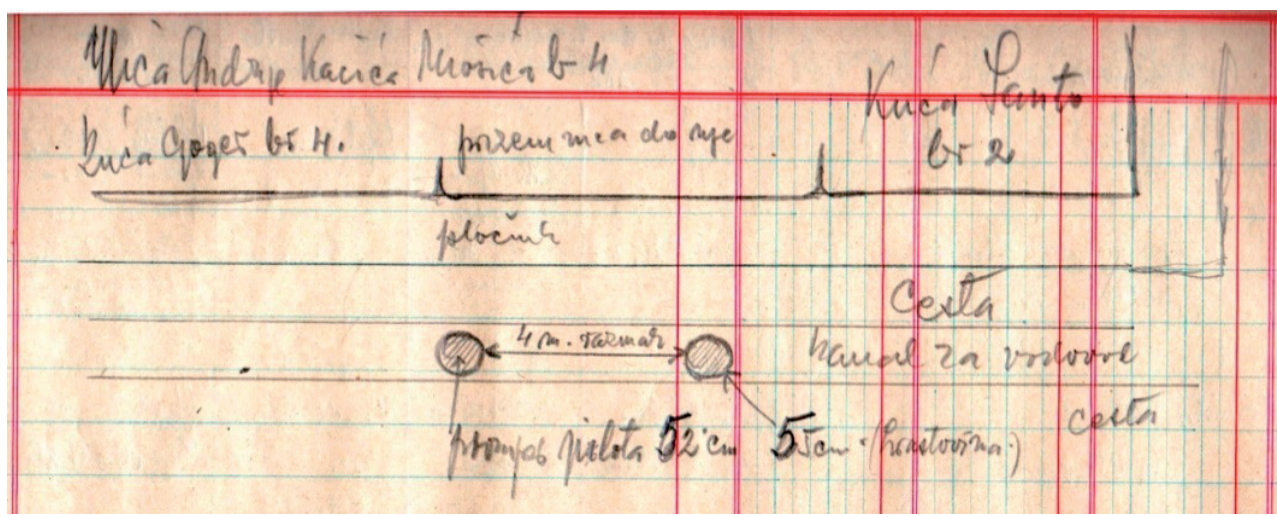

Slika 5. Sken dijela stranice terenskog dnevnika Stjepana Vukovića s ucrtanim položajem drvenih pilota nađenih u UI. Andrije Kačića Miošića, izvor: Terenski dnevnik Stjepana Vukovića, dokumentacija AO GMV-a 
Već 1962. - 1963. godine Arheološki muzej u Zagrebu, pod vodstvom Branke Vikić, vrši revizijska arheološka istraživanja u sjeverozapadnom dijelu dvorišta Starog grada, na mjestu gdje su u spomenutom iskopavanju bunara 1938. god. bili nađeni nekakvi zidovi. Arheološkim istraživanjima se na dubini od 0,7 $\mathrm{m}$ došlo do najviših dijelova tih zidova. Otkriveni su temelji neke zgrade, unutar koje su dva pregradna zida koji tvore dvije prostorije, $2 \mathrm{~m}$ široke. Također spominje se da su ti zidovi presječeni temeljem kasnije zgrade pa nije bilo moguće dobiti širu sliku ove građevine. $U$ istraživanjima su pronađeni i paljevinski ostaci hrastovog drveta te fragmenti keramike iz 13. ili 14. stoljeća. ${ }^{17}$

Na fotografijama iz 1966. god., tadašnji kustos Arheološkog odjela GMVa, Željko Tomičić dokumentirao je iskopavanje za kanalizaciju i vodovod ispred varaždinske gradske vijećnice. Iz tih fotografija vidljivi su u iskopanim rovovima paralelni zidovi, sačuvani samo u temeljnoj stopi, dok spomena o pokretnim nalazima nema. ${ }^{18}$

Veća istraživanja vršena su na Starom gradu 1970./1971. god. Tada je Jugoslavenski institut za zaštitu spomenika kulture, pod vodstvom Đorđa Mitrovića, na više lokacija sondirao varaždinski Stari grad. Ova istraživanja bila su prvenstveno arhitektonsko-konzervatorskog karaktera, tj. iskopane su manje sonde kojima su se ispitivali uglavnom temelji same utvrde te se njima nije dobilo mnogo arheoloških podataka. U dokumentaciji o ovom istraživanju se spominju nalazi zidova u raznim sondama ${ }^{19}$ i pokretni arheološki nalazi: staklo, kuhinjska i majolika keramika, pećnjaci, željezni predmeti, rogovi jelena, bakar, bronca, a spominje se i da je gotovo sav taj materijal iz „nasute šute“. Postoje samo fotografije sondi, ne i pokretnih nalaza. Iz dokumentacije se da zaključiti da je cjelokupni pokretni materijal nađen u četiri sonde i to: T (nalazila se u okolišu Staroga grada), V (dio sjeveroistočnog krila - bivše konjušnice ${ }^{20}$ ), Nj (izvan Starog grada

17 Branka VIKIĆ, Izvještaj - Arheološka istraživanja Stari grad Varaždin 1962., dokumentacija AO GMV-a; M. ŠIMEK i dr., Županija varaždinska u srednjem vijeku, 1999., 36. Za ova istraživanja Mira Ilijanić kaže da „nisu urodila značajnim rezultatima”, vidi u: Mira ILIJANIĆ, Urbanizam, graditeljstvo, kultura, zbornik radova, Varaždin, 1999., 113. - 114.

18 Fotodokumentacija AO GMV-a (snimio Željko Tomičić, 1966. god.).

$19 \mathrm{U}$ dnevniku iskopavanja s ovih istraživanja donesene su samo osnovne informacije o nalazima te istraživanje kasnije nije bilo u cijelosti objavljeno. Stoga je jako teško nešto više reći i zaključiti o pronađenim strukturama i nalazima. Ova istraživanja zahtijevaju širu i puno detaljniju revizijsku znanstvenu obradu te se stoga u ovom radu donose samo osnovni podaci o istraživanjima Starog grada '70./'71. god., kao temelj za neka buduća istraživanja.

20 Prema navodima Krešimira Filića ova zgrada je srušena u ljeto 1931. god. Vidi u: Krešimir FILIĆ, Varaždinski muzej, 1943., 16. 
u dvorištu) i X (nedaleko od žitnice uz južni zid - kula). ${ }^{21}$ Valja naglasiti da je dio pokretnog arheološkog materijala s ovih istraživanja ipak obrađen i objavljen. Riječ je o pećnjacima koje je publicirala Mira Ilijanić, koja ih vezuje uz pećarske radionice Matije Korvina i kraj 15. stoljeća. ${ }^{22}$

Jedna dokumentirana zaštitna intervencija u gradu dogodila se i 1984. god., prilikom izgradnje na prostoru današnje robne kuće Varteks u Ulici S.S. Kranjčevića. Nažalost, prilikom ovih radova nije bio propisan obavezni arheološki nadzor pa je tek trudom tadašnje kustosice AO GMV-a Marine Šimek ostalo sačuvano par fotografija prilikom iskopa te su prikupljene dvije dvokonusne boce, koje su uočene u profilu iskopa, a koje se, prema analogijama s prostora srednje Europe, datiraju u 15. - 16. stoljeće. $^{23}$

\section{RAZDOBLJE NAKON 1993. GODINE}

Premda se već 80 -ih sustavnije počelo razmišljati i raditi na zaštiti spomenika kulturne baštine varaždinske regije, konkretnijih pomaka u smislu arheoloških nadzora i istraživanja u gradu i nije bilo sve do početka 90-ih godina, kada dolazi do njihovog intenziviranja. ${ }^{24}$ Od tada započinju sustavna praćenja, arheološki nadzori i istraživanja, koja se odvijaju kontinuirano do danas. Početak ovog razdoblja je označila 1993. god. kada započinju arheološka istraživanja na dvije lokacije u užem centru grada. Oba ova istraživanja bila su zaštitnog karaktera, prilikom izgradnje poslovnih centara, a vodila ih je Marina Šimek. Prvo istraživanje provodilo se na lokaciji izgradnje Coningovog poslovnog centra na križanju Pavlinske i Šenoine ulice. Lokacija se nalazi u neposrednoj blizini istočne gradske fortifikacije. Ovim istraživanjima bila je zahvaćena površina od $110 \mathrm{~m}^{2}$, koja je istražena pomoću tri rova, dubine do $2 \mathrm{~m}$. Nađena je dobro sačuvana arhitektonska cjelina građena od kamena i drva; stepenice, vrata, dvorište sa zdencem te dovratnik. Arhitektura je tvorila gospodarsku cjelinu s ograđenim malim dvorištem i zdencem, a u zdencu je na dnu nađen zanimljiv nalaz keramičkog lonca za

21 Istraživanja Starog grada 1970. i 1971. god., dokumentacija GMV-a AO; M. ŠIMEK i dr., Županija varaždinska u srednjem vijeku, 1999., 36.

22 M. ILIJANIĆ, Urbanizam, graditeljstvo, kultura, Kasnogotički pećnjaci iz Varaždinske tvrđave, 1999., 262. - 267. Danas su neki od ovih pećnjaka dio stalnog postava Kulturno-povijesnog odjela GMV-a u Starom gradu. O pripremi za ova istraživanja vidi u: M. ILIJANIĆ, isto, 114. - 115.

23 M. ŠIMEK, Srednjovjekovno staklo iz Varaždina, 2010., 308.-310.; M. ILIJANIĆ, isto, 148.

24 Na intenzivniju brigu za gradsku arheologiju, ali i općenito kulturnu baštinu na varaždinskom području svakako je mnogo utjecalo ponovno osnivanje Zavoda za zaštitu spomenika kulture u Varaždinu u listopadu 1990. god., 22 godine nakon što je isti djelovao u Varaždinu od 1962. do 1968. god., vidi u: Ivan GRABAR, „Zaštita kulturne baštine Varaždinske županije“, Radovi Zavoda za znanstveni rad Varaždin, 10-11, 1998., 61. - 62., 81. 
uzimanje vode. Od ostalih pokretnih nalaza valja spomenuti mnoštvo keramike (glaziranog i neglaziranog posuđa), pećnjaka, stakla, metalne predmete te koštane životinjske ostatke. Većina nalaza se datira u 15. st. do kraja 17 . stoljeća. ${ }^{25}$

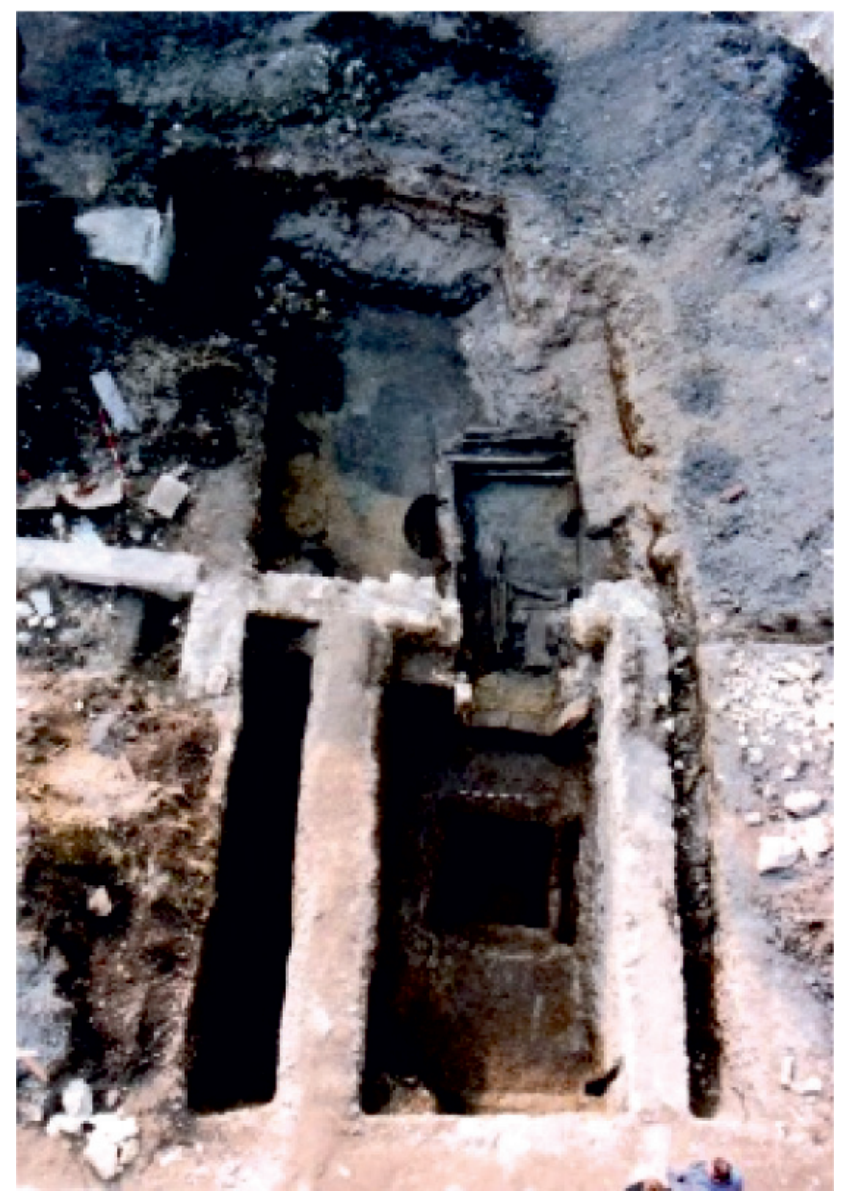

Slika 6. Pogled iz zraka na dio istraženog lokaliteta na križanju Pavlinske i Šenoine ulice. Izvor: fotodokumentacija Marina ŠIMEK, izvještaj o arheološkom istr. u gradskoj jezgri Varaždina, 1993. g. fotografija br. 15., AO GMV-a.

25 Marina ŠIMEK, Izvještaj o arheološkom istraživanju u gradskoj jezgri Varaždina, 1993., 1. - 9., dokumentacija AO GMV-a; Marina ŠIMEK, Rezultati dosadašnjih arheoloških istraživanja i konzervatorskih zahvata na području Varaždinske županije, Radovi Zavoda za znanstveni rad HAZU Varaždin, br. 10 - 11, 1998., 470., 471.; M. ŠIMEK i dr., Županija varaždinska u srednjem vijeku, 1999., 37.; Marina ŠIMEK, Ispod varaždinskih pločnika, Katalog izložbe, Varaždin, 2002. 
Sljedeće spomenuto zaštitno arheološko istraživanje iste godine se odvijalo i u Blažekovoj ulici. Čitava površina iskopa bila je podijeljena u pet rovova te je tako istražena. Nađeni su ostaci arhitekture iz 18. i 19. st. Registrirano je i 18 ukopanih objekata. Za jednu od tih jama utvrđeno je da je prvotno služila za gašenje vapna, a nađena je ispunjena novovjekovnom keramikom. Ovim istraživanjima došlo se do spoznaje da ovaj dio grada, tik uz južnu gradsku fortifikaciju, nije bio jače naseljen sve do 18 . stoljeća. ${ }^{26}$

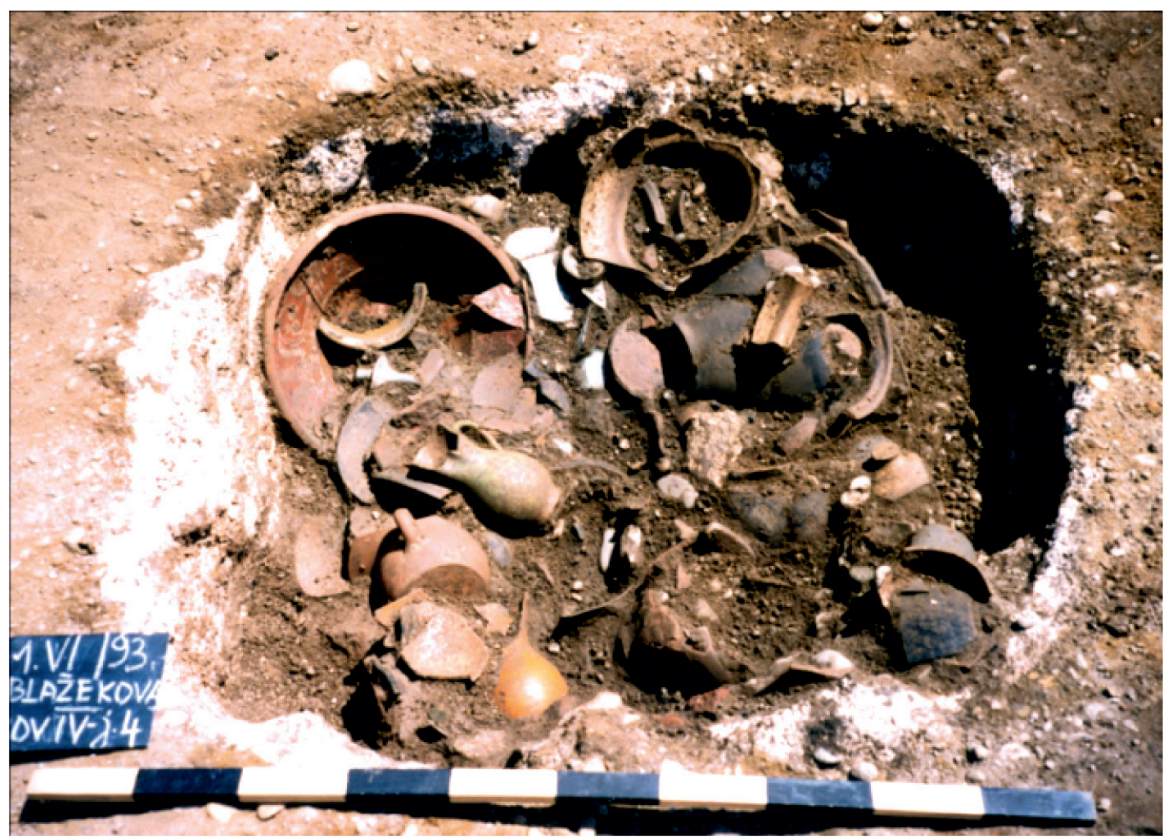

Slika 7. Fotografija jame s novovjekovnom keramikom iz Blažekove ul. Izvor: fotodokumentacija arheoloških istraživanja u Blažekovoj ul., Varaždin, 1993. god., arhiva AO GMV-a

Na lokaciji istočnog dijela Bakačeve ulice, na spoju sa Šenoinom ulicom, 1996. god. poduzeta su manja zaštitna arheološka istraživanja, zbog rekonstrukcije tog dijela ulice. Prilikom iskopa tada je pod jugoistočnim uglom zgrade tiskare „Tiva“ nađen sačuvani manji dio temeljne stope zida, za koji se ispostavilo da je dio sjeveroistočne kule u sustavu gradske fortifikacije, tj. zida. Zid je očišćen

26 Marina ŠIMEK, Izvještaj o arheološkom istraživanju u gradskoj jezgri Varaždina, Blažekova ulica, Varaždin, 1993., 1. - 7., dokumentacija AO GMV-a. 
i dokumentiran nakon čega je zatrpan. ${ }^{27}$ Godinu dana kasnije prilikom iskopa u istoj ulici, na spoju s Ulicom Ljudevita Gaja, radnici su u iskopu naišli također na dio gradskog zida. ${ }^{28}$ Krajem 1996. godine, na spoju Padovčeve ulice i Stančićevog trga, naišlo se prilikom rekonstrukcije ulice na zanimljiv nalaz. Naime, uz rubnik nogostupa, naišlo se na dio kamenog bunara. Nalaz je tada fotografiran i dokumentiran, a kasnije je i in situ prezentiran, s koritom i pumpom za vodu. ${ }^{29}$

Prilikom rekonstrukcije palače Hercer, na Franjevačkom trgu br. 6, 1998. god. započela su arheološka istraživanja. Odvijala su se u dvije kampanje do 2000. godine i na više lokacija unutar zgrade: u podrumskom dijelu zgrade i prizemnim prostorijama u sjevernom krilu zgrade. Važniji nalazi pronađeni prilikom ovog istraživanja su svakako stariji ulaz u podrum palače, na njegovoj sjevernoj strani te temelj zida koji vjerojatno pripada srednjovjekovnom xenodochiumu-hospiciju. Prikupljeno je također i mnoštvo pokretnih arheoloških nalaza: keramika, pećnjaci te staklo, datacije od kasnog srednjeg vijeka pa do 20. st. Istraživanjima se uvidjelo da je na dijelu zgrade iz 18. st. (ispod jugoistočnog dijela) postojao stariji objekt. Bio je sagrađen na nekom starijem jarku u kojem je otkrivena veća količina životinjskih kostiju. Analizom tih ostataka došlo se do spoznaje da je stariji objekt bio izgrađen vjerojatno tokom 14. st., a što se poklapa s vremenom nastanka prije u tekstu spomenutog hospicija. ${ }^{30}$

Tokom proljeća 1999. god. prilikom konzervatorskih istraživanja Gradske vijećnice u Varaždinu, stručnjaka Hrvatskog restauratorskog zavoda, dogovorena su i sondažna arheološka istraživanja podruma te zgrade, koje je vodila arheologinja GMV-a Marina Šimek. Istraživanja su vršena u podrumskim prostorijama i to u tri sonde. U svim sondama došlo se do dubine 80 - $90 \mathrm{~cm}$ od današnje površine podruma, do sloja dravskog šljunka, geološkog sloja na kojemu je i započeta gradnja ovog objekta. Stariji sloj u sondama je registriran u vidu starijeg podnog naboja podruma, koji se sastojao od lomljenog vapnenca, žbuke i sitnih fragmenata opeke. Ispod ovog sloja nalazio se sloj tamne zemlje s ostacima drvenog ugljena te manjim komadima vapnenca. Upravo iz tog sloja potječe i glavnina

M. ŠIMEK i dr., Županija varaždinska u srednjem vijeku, 1999., 37.

28 Fotodokumentacija AO GMV-a; fotokartica oznake AO F-1478; Varaždin , Bakačeva ul.

29 Fotodokumentacija AO GMV-a; fotokartice oznake AO F 1529, 1532, 1537, Varaždin, Padovčeva ul.

30 Marina ŠIMEK, Izvještaj o pokusnom arheološkom istraživanju u palači Hercer, Varaždin, 1998., dokumentacija AO GMV-a; Marina Šimek, Izvještaj-palača Hercer, Varaždin, 2000., dokumentacija AO GMV-a; M. ŠIMEK, Ispod varaždinskih pločnika, 2002. O povijesti hospicija na ovoj lokaciji piše K. Filić, vidi u; Krešimir FILIĆ, „Xenodochium vel domus hospitalis liberae ac regiae civitatis Varasdinensis“, Viestnik Hrvatskog državnog arhiva, knjiga XI, Zagreb, 1945, 165. - 186. O ovome vidi i u: M. ILIJANIĆ, Urbanizam, graditeljstvo, kultura, 1999., 121. - 122. Mira Ilijanić ga spominje kao "mjesto u koje su se sklanjale stare varaždinske građanke kada bi ostale same bez imetka". 
nađene keramike koja se datira okvirno u kraj 15. i 16. stoljeće. U ovim istraživanjima pronađen je i jedan arhitektonski element na $50 \mathrm{~cm}$ dubine od današnje hodne površine podruma na podlozi od lomljenog kamena s mnogo žbuke. Ovaj element nekakvog stupa ne povezuje se s današnjim arhitektonskim strukturama podruma. Istraživanjima nisu pronađeni tragovi starijeg objekta. ${ }^{31}$

Iste godine na adresi Padovčeva br. 2, vršen je iskop u dvorištu kuće. ${ }^{32}$ Nažalost, tu je arheološki nadzor bio necjelovit, jer su radovi na iskopu već bili počeli bez znanja arheologa. Međutim, ipak je uočen kulturni sloj debljine veće od $3 \mathrm{~m}$, s materijalom kasnog srednjeg i novog vijeka. Za pronalazak ovako debelog kulturnog sloja objašnjenje je da je građevinskim iskopom pogođeno točno mjesto ranijeg opkopa gradske fortifikacije. Također, uočen je i sloj paljevine, drvenog ugljena i šljake, a ispod kojeg je bio sloj s koncentracijom životinjskih kostiju. Otkriveni su i tragovi arhitekture, tj. dva zida, koji su djelomično već bili uništeni teškom mehanizacijom. Bili su zidani bez veziva, od lomljenca i grubo klesanog kamena. Uz jedan zid je bio i dio građen od opeke povezan sa zidom. Što se tiče pokretnih nalaza, nađeni su fragmenti stakla, grube keramike i šljake. Ove predmete bi se moglo datirati okvirno od 15. do 18. stoljeća. ${ }^{33}$

Krajem te godine u 12. mjesecu, prilikom radova na drenaži uz južni temelj zgrade br. 12 na Trgu slobode, nađene su ljudske kosti, nakon čega je bio propisan arheološki nadzor. Zbog hladnoće radovi se nisu odvijali do prve polovice veljače 2000. god. kada su započeli radovi, ali i arheološki nadzor. Nadzor je trajao nekoliko dana, a radovi su se odvijali uz južno i istočno pročelje zgrade. U rovu iskopa su nađeni željezni čavli, fragmenti zeleno glaziranog keramičkog posuđa, stakla, nalazi koji se mogu datirati u 17. - 18. stoljeća. Nedaleko od istočnog kuta zgrade nađen je veći broj fragmenata ispremiješanih ljudskih kostiju. Ovaj nalaz nije neočekivan, jer se vjerojatno još od srednjeg vijeka uz crkvu sv. Nikole nalazilo groblje, na koje se prestalo pokapati krajem 18. st. Može se zaključiti da je u 19. st. uništeno izgradnjom zgrade br. 12. Kod ovog nadzora valja spomenuti i nalaz ženske lubanje na kojoj je uočen trag nekog oglavlja. Uz nju su nađene staklene perle, bakreni okrugli listići i tri staklena oka zagasite boje. Zanimljiv je

31 Marina ŠIMEK i dr., Županija varaždinska u srednjem vijeku, 1999., 38.; Marina ŠıMEK, Izvješće o arheološkom sondiranju u podrumu gradske vijećnice u Varaždinu, 1999., dokumentacija AO GMV-a. O povijesti gradske vijećnice vidi u: M. ILIJANIĆ, Urbanizam, graditeljstvo, kultura, 1999., 11. - 13.

32 O povijesnom razvoju ove ulice piše Mira Ilijanić te spominje da su se na prostoru ove ulice u 16. st. nalazile gradske i dvorske staje, vidi u: M. ILIJANIĆ, Urbanizam, graditeljstvo, kultura, 1999., 88.

33 Marina ŠIMEK, Izvještaj o arheološkom nadzoru, Padovčeva 2-stambeno-poslovni objekt, Varaždin, 2000., dokumentacija AO GMV-a; Marina ŠIMEK, Ispod varaždinskih pločnika, 2002. Ovom prilikom zahvalio bih se gospođi Marini Šimek na danim usmenim informacijama o tijeku ovog arheološkog nadzora. 
i nalaz keramičkog, zeleno glaziranog trbušastog vrča s reljefnim ukrasima religijskog karaktera. Ovakav vrč može se datirati u 18. stoljeća. ${ }^{34}$ Sljedeći arheološki nadzor u gradu dogodio se u 11. mjesecu 2000. god. kada je zbog elektrifikacije Šetališta Vatroslava Jagića, vršen iskop više rovova u dubini do $80 \mathrm{~cm}$, a širine 40 cm. Iskopi su bili trasirani u zapadnom dijelu ovog šetališta, čiji razvoj možemo pratiti od početka 19. st., na prostoru ranije jugoistočne gradske fortifikacije i opkopa. Najznačajniji nalaz prilikom ovih istraživanja je svod kanalizacijskog susta$v^{35}$ koji je građen od kamena i opeke u 19. st. Ta struktura uočena je na zapadnoj strani šetališta, kod trafostanice, na dubini od $30 \mathrm{~cm}$. Prilikom iskopa također je na više mjesta uočen sloj šute u kojem se ponegdje uočavao i keramički materijal te staklo, koji se može datirati u 19. stoljeća. ${ }^{36}$

Prilikom sličnih radova postavljanja električnih vodova na istočnom dijelu Trga bana Josipa Jelačića 2000. god., vršen je također arheološki nadzor. Strojno su kopani rovovi širine $35 \mathrm{~cm}$ i dubine do $70 \mathrm{~cm}$. U iskopu su utvrđene četiri stratigrafske jedinice. Na najvećoj dubini od 50 do $70 \mathrm{~cm}$ sloj se sastojao od zemlje s lomljenom opekom te šutom od kamena vapnenca. Na 40 do $50 \mathrm{~cm}$ dubine nalazio se čisti šljunak, od 20 do $40 \mathrm{~cm}$ zemlja i sitni šljunak, dok se recentni sloj asfalta i podloge za isti nalazio na dubini od $20 \mathrm{~cm}$ do površine. Treba napomenuti da u iskopima nije nađen nikakav pokretni arheološki materijal. Iz stratigrafije dobivene iskopom dalo se zaključiti da se ovaj prostor sjeveroistočnog grada intenzivno nasipavao šutom kako bi se iznivelirao vlažni teren opkopa, koji se ranije nalazio na tom prostoru, te tako ovaj dio grada pripremio za urbanizaciju koja se intenzivno odvija od polovice 19. stoljeća. ${ }^{37}$

Izgradnjom vanjskog lifta uz istočni dio franjevačkog kompleksa u Varaždinu, krajem 2000. i početkom 2001. god., propisan je i arheološki nadzor. Taj kompleks u samom centru Varaždina, koji je poznat iz raznih povijesnih, arhitektonskih i arhivskih istraživanja, zanimljiv je jer nikad ranije nije bio arheološki istraživan te se ovako dobila prigoda povezati već poznate podatke o kompleksu s onima iz arheoloških istraživanja. Dolazak franjevaca u Varaždin datira se u 13. st., a današnji izgled crkve i kompleksa potječe iz vremena baro-

34 Marina ŠIMEK, Izvještaj o arheološkom nadzoru, Trg slobode, Varaždin, 2000., dokumentacija AO GMV-a; Marina ŠIMEK, Ispod varaždinskih pločnika, 2002.

35 Ovim iskopom taj stari kanal nije diran, tj. nije se zadiralo u tu strukturu. Vidi u: Marina ŠıMEK, Izvještaj o arheološkom nadzoru, Šetalište Vatroslava Jagića, Varaždin, 2000., dokumentacija AO GMV-a.

36 Marina ŠIMEK, Isto, 2000. O povijesti šetališta kojeg je osnovao Vilim Muller pisao je Rudolf Horvat. Vidi u: R. HORVAT, Povijest grada Varaždina, 1993., 292. - 293.

37 Marina ŠIMEK, Izvještaj o arheološkom nadzoru, Trg bana Josipa Jelačića, Varaždin, 2001., dokumentacija AO GMV-a. 
kne obnove. Sam arheološki nadzor vršen je uz istočno krilo samostana jer se tu radio iskop za budući vanjski lift. $U$ iskopu su pronađena dva paralelna zida, sjeverni i južni, smjera pružanja istok-zapad (od istočnog krila samostana prema samostanskoj ogradi). Širina između ova dva zida bila je $3 \mathrm{~m}$. Zbog snižene visine zidova te mnogo građevinske šute kojom su bili prekriveni, zaključuje se da su oni bili, nakon rušenja, zasipani zbog poravnavanja terena. Između ova dva zida otkriven je i jedan poprečni. Svi zidovi pokazivali su isti način gradnje (izrađeni od lomljenog i priklesanog kamena, povezanog žućkastom žbukom). Tokom istraživanja sondiralo se na spoju sjevernog i poprečnog zida, da bi se dobila dubina temeljne stope. Ona je utvrđena na $330 \mathrm{~cm}$ dubine od današnje površine. Utvrđeno je i da su zidovi građeni istovremeno te da su bili međusobno vezani. U sondiranju je nađeno i više fragmenata kuhinjskog keramičkog posuđa sa širokim izvijenim rubovima, višestruko raščlanjenim obodima kakvi su karakteristični kod posuđa kasnog srednjeg vijeka, a javljaju se već od 13. st. Na temelju tih nalaza može se jedino zaključiti da je prostorija zasipana materijalom koji se koristio kroz duži vremenski period kasnog srednjeg i ranog novog vijeka. Iz kartografskih izvora ovaj sondirani prostor poznat je od 18. stoljeća. Osim uz istočno krilo zgrade, pratili su se radovi sanacije vlage uz temelj južnog pročelja nekadašnje nemoćnice, zgrade koja je podignuta u 17. stoljeća. Uz sam temelj otkriven je okrugli bunar s vanjskim plaštem od grubo klesanog kamena. Gornji dio plašta bio je poremećen prethodnim intervencijama. Smještaj samog bunara u odnosu na zgradu, tj. njen temelj istovremen je ili možda stariji. U tom iskopu su pronađeni ispremiješani slojevi šute, crne zemlje te šljunka. Nađeno je i nešto pokretnog materijala, fragmenata glazirane i neglazirane keramike te pećnjaka koji se datiraju u širi vremenski period od kasnog srednjeg vijeka do ranog novog vijeka. ${ }^{38}$

U 10. i 11. mjesecu te iste godine odvijao se još jedan arheološki nadzor prilikom iskopa za drenažu, i to uz sjevernu i zapadnu stranu crkve sv. Florijana u Varaždinu. Građevinski radovi su počeli ranije nego je arheolog saznao za njih te su djelomično strojnim iskopom uništena dva zida i slojevi paljevine na dubini od $160 \mathrm{~cm}$ od današnje hodne površine. Nakon toga zaustavljeni su radovi te su obavljena arheološka sondiranja sa sjeverne strane crkve, na dvije pozicije. U dvorištu crkve - zapadno od pregradnog zida, te istočno od njega - uz sjeverno

38 Marina ŠIMEK, Izvještaj o arheološkom nadzoru, Franjevački samostan, Varaždin, 2001., dokumentacija AO GMV-a. O franjevcima i više faza obnove franjevačkog samostana i crkve vidi u: Rudolf HORVAT, Povijest grada Varaždina, Hrvatska akademija znanosti i umjetnosti, Zavod za znanstveni rad Varaždin, posebno izdanje, knjiga 4, Varaždin, 1993., 150., 195., 199. 
pročelje crkve. U dvorištu, uz svetište crkve, otvorena je sonda 1 koja je otkrila ostatak estriha ispod temelja svetišta današnje crkve. Vjerojatno je to dio nekog objekta starijeg od crkve. Debljina estriha je bila $20 \mathrm{~cm}$. Oko ovog estriha naknadno je zazidan bazen za gašenje vapna (pronađeno je grumenje vapna). Taj bazen je bio zasut slojem šute, koja se prema nalazima datira u 18. - 19. st. Uz ovaj bazen nađen je još jedan zid te slojevi paljevine. Nađena su i dva poprečna zida u odnosu na crkvu, koji su vjerojatno bili povezani s temeljem crkve, ali je u strojnom iskopu ta veza uništena. Sonda 2 , koja se nalazila uz sjeverno pročelje crkve, sadržavala je ostatak naboja od riječnih oblutaka, bazen za miješanje žbuke te dva zida koja su flankirala ulaz u kriptu. Ostatak naboja nađen je na 60 $\mathrm{cm}$ dubine te se interpretira kao nekadašnja uređena hodna površina oko crkve. Pronađeni bazen za miješanje žbuke datira se u 18. st., izgrađen je za jedne od većih obnova ove crkve poznate iz pisanih izvora. Kod ovog bazena pronađena je i jedna ljudska lubanja, što nam govori o vjerojatnom groblju oko crkve. Nađeni ostaci arhitektonskih i dekorativnih elemenata, vezuju se uz stariji inventar crkve sv. Florijana. Najzanimljivije otkriće do kojeg se ovim arheološkim istraživanjima došlo je ulaz u kriptu crkve, sa sjeverne strane crkve, koji je u jednom trenutku zazidan. Arhivski podaci kažu da je kripta građena tek 1773. god. Vezano uz kriptu, zanimljivo je da se na sjevernoj fasadi crkve, iznad samoga ulaza u kriptu, nalazi mali križ, kao indikator ulaza. Premda je iz arhivskih podataka poznato da je oko crkve bilo groblje, u istraživanjima nije pronađen niti jedan in situ sačuvan grob. ${ }^{39}$

Kasnija arheološka istraživanja provedena su u još dva navrata u unutrašnjosti crkve 2005. i 2007. god., kada su između ostalog otkriveni temelji crkve iz 17. stoljeća. ${ }^{40}$

Današnja gradska tržnica u Varaždinu nastala je na položaju ranijeg gradskog bedema, tj. gradskog opkopa. Zbog toga je arheološki nadzor na tom prostoru vršen 2003. god., kada su započeli radovi na rekonstrukciji tržnice. Izvođeni su zemljani radovi do dubine od $165 \mathrm{~cm}$. Sam nadzor nije započeo istovremeno s radovima već nešto kasnije. Na čitavom prostoru iskopa registriran je sloj šute, na nekim mjestima i do $90 \mathrm{~cm}$ dubine. Pronađeni su ostaci suhozidnog kanala za vodu na mjestu ranijeg opkopa. Također, pronađeni su temelji klasicistički svođene zgrade, te ostaci objekata nekadašnjih gospodarskih zgrada na istočnom

39 Marina ŠIMEK, Izvještaj o zaštitnim arheološkim istraživanjima uz kapelu sv. Florijana, Varaždin, 2002., 1. - 4., dokumentacija AO GMV-a; Marina ŠIMEK, Ispod varaždinskih pločnika, 2002.

40 Tatjana PLEŠE, Rezultati zaštitnih arheoloških istraživanja - kapela sv. Florijana, Varaždin, 2007., 4. 5., dokumentacija AO GMV-a. 
dijelu tržnice. Uz rub tržničkog prostora, u Preradovićevoj ulici pronađeno je više obrađenih kamenih okvira. Od manjih pokretnih nalaza valja spomenuti nalaz četiri kovanice kod crkve sv. Đorđa te metalne industrijske klinove u sjeveroistočnom dijelu. ${ }^{41}$ Početkom 2003. god. u Bakačevoj ulici na kućnom broju 2 vrši se arheološko iskopavanje zbog izgradnje novog objekta na mjestu postojećeg. Iz povijesnih izvora nam je poznato da je na prostoru ove ulice ranije bio gradski zid te se spominju i mesarski dućani. Prilikom istraživanja otvorene su četiri sonde do dubine od 1 metra. Dvije su bile u dvorišnom dijelu, a dvije u kući predviđenoj za rušenje. Niti jedna sonda nije istražena do sterilnog sloja, a razlog je skučenost sondi. U sondi 1 je u nasipu dvorišta otkriven kameni slivnik te kameni zid pružanja istok-zapad, koji po načinu gradnje, dimenzijama i položaju odgovara ostacima gradskog bedema. Sačuvan je u visini od $80 \mathrm{~cm}$. U stratigrafskoj jedinici 7, a u toj sondi, otkriven je veliki depozit životinjskih kostiju, što potvrđuje pretpostavku da su tu postojale mesnice, koje se spominju u izvorima na tom prostoru kroz duži vremenski period. Nađen je još i loše građeni ostatak zida u sjevernom dijelu sonde, vjerojatno ostatak nekakvog pomoćnog objekta. U sondi 2, uz zid susjedne kuće prema zapadu dvorišta, otkriveno je krunište kamenog bunara, koji dijelom ulazi i pod zid, tj. na susjednu parcelu. Uz bunar je bilo popločanje od kamena i dijelom od opeke sa žbukom. Sonde 3 i 4 unutar kuće su otkrile još jedan segment zida, koji se pruža u smjeru istok-zapad, a koji bi također mogao biti interpretiran kao jako oštećen segment gradskog bedema. U sondi 3 , ispod daščane podnice kuće, otkriven je objekt nepoznate namjene, građen od opeka vezanih žbukom te popločanje od kamenih ploča na kojima je uočen sloj gara od $30 \mathrm{~cm}$. U sondi 4 otkriven je još jedan temelj objekta nepoznate namjene. Vanjski tlocrt tog objekta bio je pravokutan, a unutarnji zaobljen. Otkrivena struktura nije se mogla preciznije datirati, niti joj se mogla odrediti namjena. Moglo se jedino zaključiti da je objekt izgrađen s vanjske strane gradskog zida. Pokretni nalazi u ovim sondama bili su uglavnom fragmenti kuhinjske keramike sa zelenom ili smeđom glazurom te manja količina stakla i porculana. U posebne nalaze izdvaja se nalaz pećnjaka u obliku ženske glave, nekoliko staklenih bočica i mesingani ukrasni okov. Svi ovi nalazi okvirno su datirani u 18. - 19. stoljeća. ${ }^{42}$

41 Spomenka TEŽAK, Izvještaj o arheološkom nadzoru - gradska tržnica u Varaždinu, 2002., dokumentacija AO GMV-a.

42 Šimek, M., Izvještaj o arheološkim istraživanjima u Bakačevoj ulici br. 2 u Varaždinu, dokumentacija AO GMV-a, 2003. 


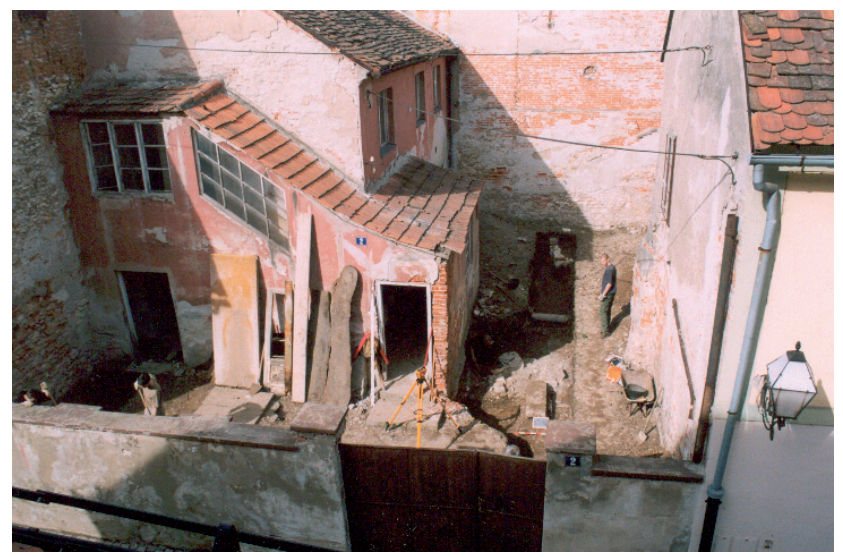

Slika 8. Fotografija arheoloških istraživanja na lokaciji Bakačeva ul. br. 2 Izvor: fotodokumentacija AO GMV-a (Bakačeva ul., br. 2)

Prva sustavna arheološka istraživanja u gradu Varaždinu provodila su se 2006. god., kada se pod okriljem tzv. projekta Bastion, u suradnji s Pokrajinskim muzejom Maribor i Mestnom občinom Maribor, provode arheološka sondiranja na vanjskom prostoru Starog grada. Cilj projekta bio je istraživanje i predstavljanje javnosti obrambenih sustava 16. st. u gradovima Mariboru i Varaždinu te poticanje što boljeg shvaćanja zajedničke kulturne baštine. Arheološka istraživanja na varaždinskom Starom gradu imala su za cilj prikupiti podatke o sustavu obrane renesansne utvrde. Ovim iskopavanjem su istraženi dijelovi sjevernog, zapadnog i južnog bedema te dijelovi unutarnjeg južnog i zapadnog mokrog jarka te dio suhog jarka uz ulaznu kulu Starog grada. Ukupno je otvoreno 11 sondi, a istražena površina iznosi $805 \mathrm{~m}^{2}$. Istraživanja su dala nove podatke o utvrdi, zemljanim bedemima te fortifikaciji prije renesansnog građevinskog zahvata. Također pribavljena je i velika količina pokretnih nalaza, većinom iz mokrog jarka u koji je, čim je izgrađen, započelo bacanje smeća koje se tu taložilo stoljećima. Stoga nije ni čudo što su tu nađeni keramika, staklo, porculan, razni metal te kameni elementi, datacije od 15. do 20. stoljeća. Pokazalo se da su bedemi na istraženim dijelovima građeni samo od šljunka i zemlje, s različitim slojevima popravaka i intervencija. Prilikom istraživanja mokrog jarka otkriveno je da je bio dubok 170 - $180 \mathrm{~cm}$ te da mu je širina bila $28 \mathrm{~m}$. Također, za izolaciju utvrde od vode koristili su se slojevi gline, jer je voda u dijelovima dodirivala zidove same utvrde. Jedini segment kamenog zida otkriven je u južnom zemljanom bedemu. Radi se o segmentu gradskog zida, koji je prezentiran in situ. Još jedan zanimljivi fortifikacijski element ove utvrde je i ostatak drvenih obrambenih konstrukcija, 
palisada te drvenog mosta ili rampe kojom se prilazilo sjevernoj strani četvrtaste gotičke kule Starog grada. Dendrokronološkom analizom je potvrđeno da se radi o vremenu prije renesansne obnove utvrde, tj. razdoblju sredine 15 . stoljeća. ${ }^{43}$

Arheološki nadzor te zaštitna arheološka istraživanja 2007. god. provođena su na rubnom dijelu povijesne gradske jezgre Varaždina, u Preradovićevoj ulici br. 14, na parceli neposredno uz Prvu gimnaziju Varaždin. Ta istraživanja provodilo je Ministarstvo kulture, Uprava za zaštitu kulturne baštine, Konzervatorski odjel u Varaždinu pod vodstvom Marijane Korunek. Cilj ovih istraživanja bila je determinacija gradskog opkopa za koji je iz arhivskih i kartografskih podataka poznato da je bio izgrađen na ovom prostoru. Istraženo je ukupno šest sondi te utvrđeno ukupno 13 stratigrafskih jedinica. Pronađen je opkop koji se nalazio iznad geološkog sloja dravskog šljunka. U opkopu je u isušenom mulju pronađeno i najviše pokretnih nalaza: keramike (oslikana, glazirana i neglazirana), pećnjaka, stakla i metalnih predmeta. Iz povijesnih izvora poznat je podatak da je opkop sustavno zatrpavan od početka 19. stoljeća. Što se tiče nepokretnih nalaza, uz istočni kameni zid parcele pronađen je bunar, te do njega popločanje od opeke. Također, pronađen je i jedan zid od opeke. Svi ovi nepokretni nalazi nađeni su na razini funkcioniranja terena u 19. i 20. stoljeća. Pokretni arheološki materijal okvirno se može datirati od 15. pa do 19. stoljeća. ${ }^{44}$

Iste godine provodi se arheološki nadzor i zaštitno iskopavanje u Vodnikovoj ulici br. 2-4. Ova ulica smještena je nedaleko od crkve sv. Florijana, tj. nešto sjevernije od nje. Dvije sonde pokazale su da se lokalitet može datirati od 18. stoljeća. do danas. Za najstariju kuću u kompleksu iz izvora je poznato da je izgrađena sredinom 18. stoljeća. U sondama je, što se tiče nepokretnih nalaza, otkriven kameni temelj objekta izgrađenog u 20. stoljeća. Prva sonda nije dala toliko pokretnih nalaza ali je zato u sondi 2 pronađeno mnogo različitog pokretnog materijala. Nađeni su predmeti od razne vrste keramike, porculana, stakla, lule za pušenje te željezne pređice. Svi predmeti mogu se datirati okvirno od 18 do 20 . stoljeća. ${ }^{45}$

43 Marina ŠIMEK, Izvještaj; Varaždin - Stari grad, arheološka istraživanja 2006. god., dokumentacija AO GMV-a, 2007., 1. - 15. Rezultati ovih istraživanja objavljeni su u publikaciji: Marina ŠıMEK, „Arheološka istraživanja varaždinske utvrde i projekt Bastion“, Podravina, volumen VII, broj 13, Koprivnica, 2008., 5. - 12., Rezultati dendrokronološke analize u: Katarina ČUFAR, Marina ŠIMEK, „Dendrochronological investigation of wood from Varaždin Old Castle“, Podravina, volumen VII, br. 13, Koprivnica, 2008., 22. - 29.; vidi i u: Marina ŠIMEK, Arheologija bedema i opkopa, u katalog izložbe; Iz srednjega u novi vijek, varaždinski Stari grad i projekt Bastion, Varaždin, 2008., 19. - 31.; Vidi i u: Mirela SLUKAN ALTIĆ, Povijesni atlas gradova V. svezak, Varaždin, 2009., 46.

44 Marijana KORUNEK, Rezultati zaštitnih arheoloških istraživanja i arheološkog nadzora, PRVA GIMNAZIJA-Preradovićeva 14, Varaždin, 2007., 1. - 29., dokumentacija AO GMV-a.

45 Martina JURIŠIĆ, Izvještaj o zaštitnom arheološkom istraživanju na lokalitetu Vodnikova - Varaždin, 2008., 3. - 7., dokumentacija AO GMV-a. 
Na poziciji Kapucinskog trga provodio se arheološki nadzor te istraživanje zbog građevinskih radova u više navrata kroz 2010. godinu. Od strane Konzervatorskog odjela u Varaždinu propisan je arheološki nadzor jer se iz arhivskih izvora zna da je na tom prostoru u prošlosti funkcionirao jugozapadni obrambeni sklop grada, s bedemom, bastionom i opkopom. Ovim istraživanjem to je djelomično i potvrđeno, jer je na jednom dijelu iskopa registriran položaj samog opkopa, njegova širina od $80 \mathrm{~m}$ te prosječna dubina od $130 \mathrm{~cm}$. Osim ovoga nije registrirana nikakva druga arhitektura koja bi se mogla vezati uz gradske obrambene zidove ili kulu. Razlog tomu možda leži u činjenici da čitav prostor trga u trenutku istraživanja nije bio dostupan za sondiranje. Unutar potvrđenog opkopa, pronađen je glinoviti sloj kojim se isti izolirao. Tokom istraživanja otkriven je i sloj smeđe zemlje, kojom je opkop bio zasipan i niveliran, a što je bila potvrda i povijesnih izvora koji spominju uklanjanje gradskih zidova i opkopa u 19. stoljeća, zbog širenja grada i prestanka ratne opasnosti za grad. Upravo u ovom sloju je pronađeno i najviše pokretnih arheoloških nalaza, koje se može datirati od 18. do 20. st., a radi se uglavnom o glaziranoj i neglaziranoj kuhinjskoj te stolnoj keramici, staklenim bocama i bočicama. U muljevitom sloju, koji je označen kao sloj opkopa, nađeno je nešto životinjskih kostiju, potkova te grublje keramike karakteristične za kasni srednji vijek i rani novi vijek, što bi odgovaralo vremenskom periodu funkcioniranja samog opkopa. ${ }^{46}$

U svibnju 2011. god. proveden je manji arheološki nadzor na položaju nedaleko od Lančane kule na Starom gradu, jugozapadno od nje. Iskop je bio relativno plitak, dubine od 45 do $50 \mathrm{~cm}$. Na toj dubini otkriven je sloj podnice, tj. estriha. Ova podnica bi se, prema pisanim izvorima, mogla pripisati podnici spremišta za vatrogasce, izgrađenog od strane vatrogasnog društva, u 18. st. Na podnici nisu uočeni nikakvi pokretni arheološki nalazi. ${ }^{47}$

Sljedeće godine na kućnom br. 6 u Padovčevoj ulici odvijao se arheološki nadzor zbog izgradnje bazena i strojarnice u dvorištu kuće koja se nalazi $13 \mathrm{~m}$ od jugoistočnog ugla „Kule stražarnice“ Starog grada, dakle na mjestu nekadašnjeg sustava gradskih bedema i opkopa. Dubina iskopa za bazen išla je do 1,75 m, a za strojarnicu do 1,80 m. Na 1,5 m relativne dubine uočen je sloj tamnije masne zemlje, s većom koncentracijom fragmenata keramike i željeza. U ovoj relativno maloj sondi pronađen je veći broj tipičnih nalaza za područje centra grada, kao što su novovjekovna keramika, fragmenti željeza, stakla i pećnjaka. ${ }^{48}$

46 Marina ŠIMEK, Izvještaji o arheološkom nadzoru 2010. g. Varaždin - Kapucinski trg, svibanj, kolovoz, prosinac 2010., dokumentacija AO GMV-a.

47 Marina ŠIMEK, Izvještaj o arheološkom nadzoru, Varaždin-Stari grad,2011., dokumentacija AO GMV-a.

48 Maja GRGURIĆ, Izvještaj arheološkog nadzora, Lokalitet - Varaždin, Ul. Ivana Padovca 6, rezultati i zaključak nadzora, Varaždin, 2012., dokumentacija AO GMV-a. 
Prilikom rekonstrukcije 2014. god., Draškovićeve i Školske ulice koje omeđuju crkvu sv. Nikole, propisan je arheološki nadzor od strane Konzervatorskog odjela u Varaždinu. Iako su građevinski radovi praćeni od početka, na pojedinim pozicijama uočeno je da je stratigrafija poremećena i to prethodnim građevinskim radovima koji su se ovdje odvijali prije 20 -ak ili više godina. Premda su slojevi bili poremećeni i u ovim su iskopima prikupljeni zanimljivi pokretni nalazi 16. i 17. stoljeća. Na pojedinim dijelovima Školske ulice ipak je bilo moguće pratiti

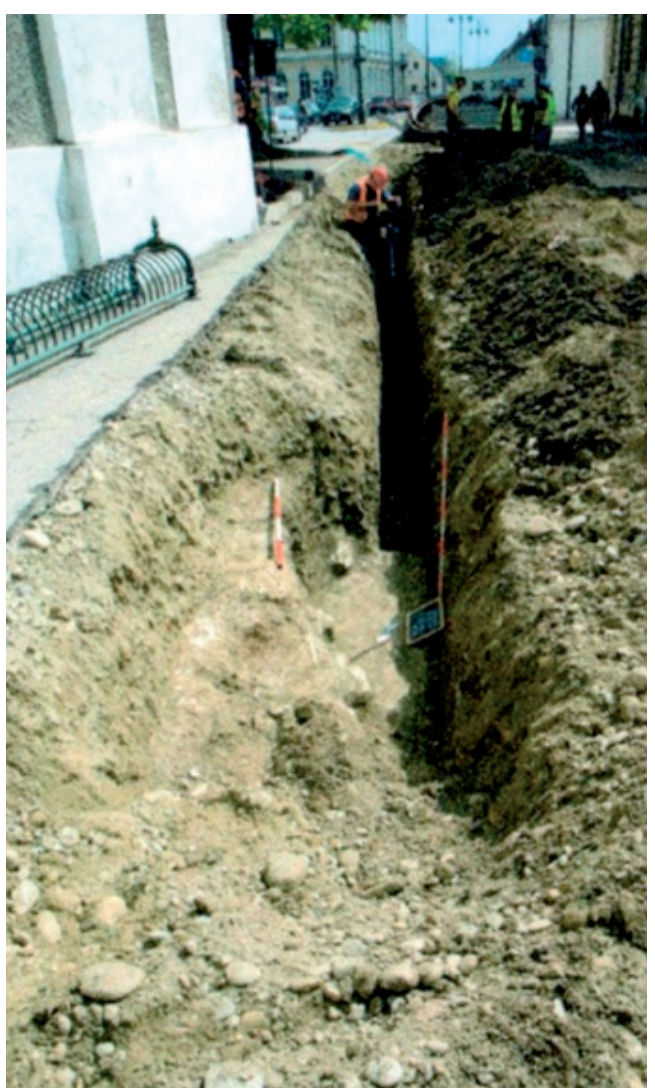
stratigrafski neporemećene slojeve. Otkrivene su ukupno četiri stratigrafske jedinice. Kulturni sloj sive do crne boje otkriven je na dubini od 100 do $120 \mathrm{~cm}$. Svi pokretni nalazi pronađeni su u tom kulturnom sloju, a datiraju se u širi vremenski period od 15. do 19. stoljeća. Radi se o glaziranoj, slikanoj i neglaziranoj keramici, pećnjacima, staklu, ali i nalazima životinjskih kostiju. Posebno zanimljiv nalaz ovog arheološkog nadzora je dio zida i podnice, koji su pronađeni ispred ulaza u crkvu sv. Nikole, u Draškovićevoj ulici. Za ovu arhitekturu se pretpostavlja da vjerojatno pripada nekoj od ranijih faza crkve. Točno kojoj fazi, zbog ograničavajuće širine iskopa, nije se moglo definirati. Arhitektura je nakon iskopa zaštićena geotekstilom te prekrivena pijeskom tako da bude sačuvana za neka buduća istraživanja. ${ }^{49}$

Slika 9. Fotografija arhitekture pronađene ispred pročelja crkve sv. Nikole Izvor: fotodokumentacija AO GMV-a

49 Marina ŠIMEK, Izvještaj o arheološkom nadzoru 2014. godine, Ulica Janka Draškovića i Školska ulica, Varaždin, 2014., dokumentacija AO GMV-a. 
Prostor uz južni dio Pavlinskog sklopa na istočnom dijelu gradske jezgre Varaždina, točnije Habdelićeva ulica, arheološki je istraživan prilikom njene rekonstrukcije te izgradnje hotela Park Butique na južnoj strani ove ulice. Radovi, a tako i arheološki nadzori odvijali su se kroz 2014. i 2015. godinu. Tokom 2014. god. Provođen je nadzor pri kopanju temelja za prije spomenuti hotel i restoran i to do dubine od $4 \mathrm{~m}$, tj. do geološkog sloja dravskog šljunka i pijeska. Premda je nadzor bio otežan zbog brzine radova, prikupljeno je dosta pokretnog arheološkog materijala. Radi se o kućnoj keramici, pećnjacima, fragmentima fine stolne keramike, staklu te pločastom kamenju. Pronađeni materijal datira se od 16 do 19. stoljeća. U iskopu je također registrirana i jedna otpadna jama s materijalom iz 19. stoljeća. Što se tiče nepokretnih nalaza, u južnom dijelu iskopa otkriven je otvor bunara, kojeg nije bilo moguće u potpunosti istražiti jer je za vrijeme nadzora počela prodirati voda. Većina ovih pokretnih nalaza je najvjerojatnije na ovome mjestu završila kao smeće koje se bacalo u vrtove i okućnice uz južni gradski zid. Tijekom arheološkog nadzora 2015. god., za vrijeme rekonstrukcije same Habdelićeve ulice, uočeno je da je stratigrafija ulice potpuno poremećena ranijim prekopavanjima. Kompaktniji sloj bio je vidljiv tek u sjevernom profilu iskopa za kanalizaciju i to u vidu crnog paljevinskog sloja masne zemlje, a koji je sadržavao veće količine životinjskih kostiju te fragmente drvene arhitekture. Sljedeći sloj u stratigrafiji bio je nešto svjetliji tamnosmeđi sloj zemlje s mnoštvom fragmenata obične i glazirane novovjekovne keramike i pećnjaka. I ostali pokretni nalazi, koji su nađeni u Habdelićevoj ulici, sličnih su karakteristika, ali su nađeni u prekopanim slojevima te stoga nemaju arheološki kontekst, a isto tako nije sigurno je li ovo prvotni kontekst tih predmeta ili je donesen s drugih lokacija u 19. stoljeću. za nivelaciju terena opkopa. Sav materijal datira se od 16 . do 19 stoljeća. Što se tiče nepokretnih nalaza, pronađen je zid koji je moguće povezati s ogradom isusovačkog kolegija, čija je gradnja započela u 17. stoljeću. Također pronađen je i zid smjera pružanja istok-zapad na dubini od 1,50 m, zapadno od sjecišta Habdelićeve ulice sa Stepinčevom, te se ovaj zid vezuje uz ostatke gradskog obrambenog zida izgrađenog u 16 . stoljeću. ${ }^{50}$

\section{ZAKLJUČAK}

Dosada provedena arheološka istraživanja u gradu Varaždinu, prema dostupnoj dokumentaciji, bila su uglavnom manjeg obuhvata i u najvećoj mjeri zaštit-

50 Marina ŠIMEK, Izvještaj o arheološkom nadzoru 2014. god., Habdelićeva ulica - Varaždin, 2014., dokumentacija AO GMV-a; Ivančica PEHARDA, Izvještaj o arheološkom nadzoru 2014. god., Ulica Jurja Habdelića - Varaždin, 2016., dokumentacija AO GMV-a. 
nog karaktera, tj. radilo se o arheološkim nadzorima. U prvom razdoblju istraživanja u gradu (do kraja Drugog svjetskog rata), interes istraživača bazirao se prvenstveno na utvrdu Stari grad, prilikom čije je obnove dolazilo do sporadičnih manjih, mogli bismo ih nazvati pokušaja istraživanja, s obzirom da se nije radilo o metodološki provedenim arheološkim istraživanjima. Najviše je u tom razdoblju istraživao tadašnji ravnatelj Gradskog muzeja Varaždina, a najbitnije za to razdoblje je da se počelo s istraživanjima u gradu i da su otkrivene neke nove strukture, kao 1941. god. dvorišna ulazna kula utvrde. Nakon toga slijedi razdoblje u kojem se fokus prebacuje i na ostalu urbanu jezgru Varaždina, ali do 90-ih godina 20. st. bili su to samo sporadični (manje ili više) uspješni pokušaji arheologa kustosa GMV-a da se prilikom radova u užem centru grada sačuva i istraži arheološka baština Varaždina. Valja pri tome istaknuti 1954. godinu kada, tadašnji kustos AO GMV-a, arheološki istražuje nalaz Brvnare na trasi kanalizacije na današnjem Franjevačkom trgu. Taj događaj možemo smatrati začetkom gradske arheologije u Varaždinu. Protokom vremena, a usporedno s općenito popularizacijom gradske arheologije među strukom, od 90-ih godina 20. st. do danas arheološka istraživanja u gradu su postala sve brojnija. Pod vodstvom i na poticaj tadašnje kustosice GMV-a Marine Šimek, započeo je intenzivniji arheološki nadzor čitave jezgre grada pri svakom većem iskopavanju. Ona je tokom tog razdoblja provela i većinu arheoloških istraživanja koja su se provodila u gradu, naravno sa svom popratnom dokumentacijom, te je time uvelike zaslužna za razvoj gradske arheologije Varaždina. U tih 80 godina, od 1938. god., istražene su ukupno 24 lokacije, dok se prostor unutar areala utvrde Stari grad tokom ovog razdoblja istraživao u šest navrata, te je tako mnoštvo pokretnih i nepokretnih arheoloških nalaza ugledalo svjetlo dana. Kada usporedimo nalaze i slojeve u čitavom gradu, vidljivo je da niti jedno istraživanje (zasada) nije otkrilo nikakve nalaze ni slojeve starije od srednjeg vijeka, tj. prema dosadašnjem stanju istraženosti ne može se reći da je sama jezgra Varaždina bila naseljena i u tim razdobljima. Suprotno ovome, povijesno razdoblje kasnog srednjeg i ranog novog vijeka, tj. razdoblje renesanse snažno se očituje upravo u brojnom arheološkom materijalu nađenom tokom gotovo svih istraživanja u gradu. Ne treba to čuditi jer je to potvrda upravo onoga što znamo i iz povijesnih izvora; da je grad Varaždin u spomenutom razdoblju doživljavao svoju „renesansu“, tj. nagli rast i razvoj.

Stoga, premda gotovo nevidljivo na površini grada, razdoblje kasnog srednjeg i ranog novog vijeka, zbog raznih razloga, ipak je jako vidljivo čim „zagrebemo" malo ispod površine. Osim najbrojnijih pokretnih nalaza iz spomenutog razdoblja, na nekim lokacijama u gradu su pronađeni i dijelovi arhitekture (drvene i kamene), kao vjerni svjedoci upravo tog vremena. Dobar primjer takve 
arhitekture je brvnara nađena u istraživanjima Franjevačkog trga iz 15. stoljeća, drvena palisada u sjevernom unutarnjem opkopu utvrde Stari grad, također iz 15. stoljeća, ali i sklop renesansne arhitekture nađene tokom istraživanja na križanju Pavlinske i Šenoine ulice.

Veseli pozitivan trend i činjenica, da na prostoru jezgre grada Varaždina postoji sada već uhodana praksa arheoloških nadzora i po potrebi zaštitnih arheoloških istraživanja, što će u budućnosti, nadamo se, omogućiti sagledavanje još cjelovitije arheološke i povijesne slike grada, te bi to posljedično moglo omogućiti bolje sustavno planiranje grada i očuvanje svih aspekata arheološke baštine. U cilju boljeg razumijevanja i lociranja pozicija istraživanja u gradu, sva su ucrtana na moderni plan grada, ali i na stari plan, koji ima ucrtane sve fortifikacijske elemente, te je tako dobiven barem približan uvid u njihovu prostornu prošlost. Upravo kad gledamo tako ucrtane točke na planu, vidljivo je kako su dosadašnja arheološka istraživanja samo jedan mali dio arheološkog mozaika grada, koji bi se svakim budućim arheološkim istraživanjima i dokumentiranjima trebao nadopunjavati, a sve u cilju boljeg razumijevanja i očuvanja zajedničke kulturne baštine Varaždina.

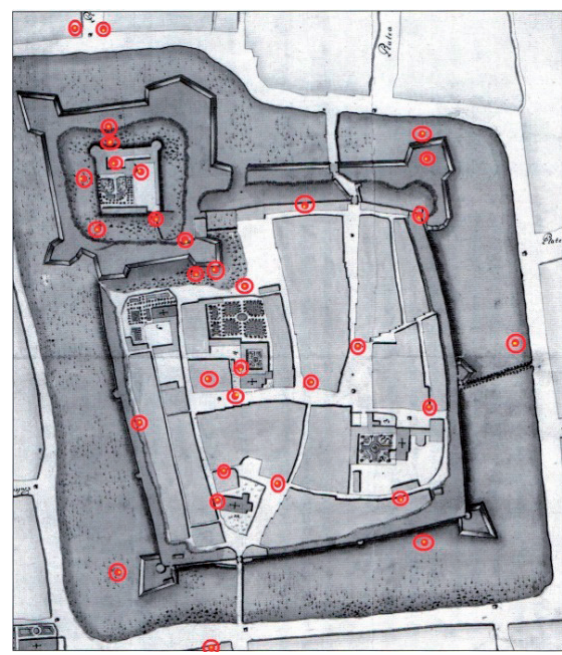

Slika 10. Crvenim točkama ucrtane pozicije arheoloških nadzora i istraživanja arheoloških nadzora u Varaždinu, Kneidingerov plan iz 1766. g.

(Izvor: M. Slukan Altić, Povijesni atlas gradova, Varaždin, 2009., 100.; ucrtao Jere Drpić)

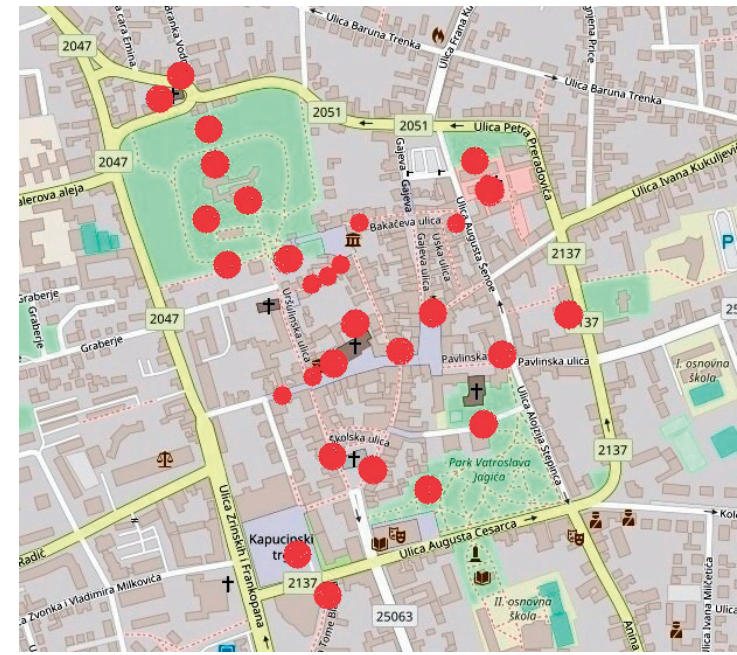

Slika 11. Crvenim točkama ucrtane pozicije arheoloških i istraživanja u Varaždinu, (Izvor: https://www.google.com/maps, ucrtao; Jere Drpić) 


\section{LITERATURA}

Knjige i članci u časopisima

1/ Registar arheoloških nalaza i nalazišta sjeverozapadne Hrvatske, Muzejsko društvo sjeverozapadne Hrvatske - sekcija arheologa i preparatora, Bjelovar, 1997.

2/ Aleksandra BUGAR, Boris MAŠIĆ, „U službi arheologije, Gospođa NN iz 13. stoljeća“, Zagreb moj grad 7, 44, Zagreb, 2013., 86.-87.

3/ Ana AZINOVIĆ BEBEK, „Novovjekovna arheologija u Hrvatskoj - Problemi metodologije, terminologije i imena", Prilozi Instituta za arheologiju u Zagrebu, 35/2018, Zagreb, 2018., 302.

4/ Katarina ČUFAR, Marina ŠIMEK, „Dendrochronological investigation of wood from Varaždin Old Castle“, Podravina, volumen VII, br. 13, Koprivnica, 2008., 22.-29.

5/ Krešimir FILIĆ, Varaždinski muzej, vodič stalnim postavom, Varaždin, 1943.

6/ Krešimir FILIĆ, „Xenodochium vel domus hospitalis liberae ac regiae civitatis Varasdinensis", Viestnik Hrvatskog državnog arhiva, knjiga XI, Zagreb, 1945., 165.-186.

7/ Ivan GRABAR, „Zaštita kulturne baštine Varaždinske županije“, Radovi Zavoda za znanstveni rad Varaždin, 10-11, Varaždin, 1998., 55.-84.

8/ Rudolf HORVAT, Povijest grada Varaždina, Hrvatska akademija znanosti i umjetnosti, Zavod za znanstveni rad Varaždin, posebno izdanje, knjiga 4, Varaždin, 1993.

9/ Mira ILIJANIĆ, Urbanizam, graditeljstvo, kultura, zbornik radova, Varaždin, 1999.

10/ Miroslav KLEMM, Marina ŠIMEK, Spomenka TEŽAK, „Iz srednjega u novi vijek: varaždinski Stari grad i project Bastion“, Katalog izložbe, Gradski muzej Varaždin, Varaždin, 2008.

11/ Robert MATIJAŠı́́, „Urbana arheologija u Puli“, Histria Antiqua 1/1995, Pula, 1995., 37.-46.

12/ Mirela SLUKAN ALTIĆ, Povijesni atlas gradova V. svezak Varaždin, 2009.

13/ Marina ŠIMEK, „Rezultati dosadašnjih arheoloških istraživanja i konzervatorskih zahvata na području Varaždinske županije“, Radovi Zavoda za znanstveni rad HAZU Varaždin, br. 10 - 11, Varaždin, 1998., 455.-475.

14/ Marina ŠIMEK, „Dvije ostruge kasnog srednjeg vijeka iz Varaždina“, Opvsc. archaeol. 23-24, Zagreb, 1999./2000., 347.-351.

15/ Marina ŠIMEK, Ispod varaždinskih pločnika, katalog izložbe, Gradski muzej Varaždin, Varaždin, 2002. 
16/ Marina ŠIMEK, „Ausbauen-ausgraben, Stadtarchäologie in Varaždin; Spannungsfeld Altstadttiefgarage, Stadtplanung und Stadtarchäologie", Schild von Steier, Kleine Schriften, 20, Graz, 2004., 82.-87.

17/ Marina ŠIMEK, „Arheološka istraživanja varaždinske utvrde i projekt Bastion", Podravina, volumen VII, broj 13, Koprivnica, 2008., 5.-12.

18/ Marina ŠIMEK, „Srednjovjekovno staklo iz Varaždina“, Archaeologia Adriatica IV, Zadar, 2010., 307.-324.

19/ Spomenka TEŽAK, Marina ŠIMEK, Tomislav LIPLJIN, Županija varaždinska u srednjem vijeku, katalog izložbe Gradskog muzeja Varaždin, Varaždin, 1999.

20/ Jasna TOMIČıć, „Varaždinska brvnara“, Muzejski vijesnik 6, Čakovec, 1983., 55.-57.

21/ Željko TOMIČić, „,Važnost nalaza ranosrednjovjekovnog koplja u Varaždinu“, Starohrvatska prosvjeta s. III, sv. 10, Zagreb, 1968., 53.-61.

\section{Dokumentacija Arheološkog odjela Gradskog muzeja Varaždin}

Marina ŠIMEK;

- terenski dnevnik, Varaždin-Stari grad, 1987.

- Izvještaj o arheološkom istraživanju u gradskoj jezgri Varaždina, 1993.

- Izvještaj o arheološkom istraživanju u gradskoj jezgri Varaždina, Blažekova ulica, 1993.

- Izvještaj o pokusnom arheološkom istraživanju u palači Hercer, Varaždin, 1998.

- Izvješće o arheološkom sondiranju u podrumu gradske vijećnice u Varaždinu, Varaždin, 1999.

- Izvještaj o arheološkom nadzoru, Varaždin-Padovčeva 2-stambeno-poslovni objekt, Varaždin, 2000.

- Izvještaj o arheološkom nadzoru na Trgu slobode, Varaždin, 2000.

- Izvještaj o arheološkom nadzoru, Šetalište Vatroslava Jagića, Varaždin, 2000.

- Palača Hercer, Varaždin, 2000.

- Izvještaj o arheološkom nadzoru-Trg bana Jelačića; istočni dio, Varaždin, 2001.

- Izvještaj o arheološkom nadzoru, Franjevački samostan, Varaždin, 2001.

- Izvještaj o zaštitnom arheološkom istraživanju uz kapelu sv. Florijana u Varaždinu, Varaždin, 2002.

- Izvještaj o arheološkom istraživanju u Bakačevoj ul. Br. 2 u Varaždinu, Varaždin, 2003. 
- Izvještaji o arheološkom nadzoru 2010. g. Kapucinski trg, Varaždin, svibanj, kolovoz i prosinac 2010.

- Izvještaj o arheološkom nadzoru, Varaždin-Stari grad, 2011.

- Izvještaj o arheološkom nadzoru 2014. godine, Ulica Janka Draškovića i Školska ulica, Varaždin, 2014.

- Izvještaj o arheološkom nadzoru 2014. g., Habdelićeva ulica - Varaždin, 2014.

Martina JURIŠı́́;

- Izvještaj o zaštitnom arheološkom istraživanju na lokalitetu Vodnikova-Varaždin, 2007. g., Varaždin, 2008.

Marijana KORUNEK

- Rezultati zaštitnih arheoloških istraživanja i arheološkog nadzora, Prva gimnazija, Preradovićeva 14, Varaždin, 2007.

Ivančica PEHARDA;

- Izvještaj o arheološkom nadzoru 2014. g., Ulica Jurja Habdelića - Varaždin, 2016.

Tatjana PLEŠE;

- Kapela sv. Florijana, Varaždin, rezultati zaštitnih arheoloških istraživanja, Zagreb, 2007.

Spomenka TEŽAK;

- Izvještaj o arheološkom nadzoru, gradska tržnica Varaždin, 2002.

Stjepan VUKOVIĆ;

Terenski dnevnik, dosje o lokalitetu Varaždin-Brvnara, 1954.

\section{Ostala dokumentacija}

Državni arhiv u Varaždinu, opći spisi 1942., kat. 44, br. 4173

\section{Internet:}

- https://www.google.com/maps

- (http://library.foi.hr/novine/) preuzeto 10.11.2018.

- (http://www.mgz.hr/hr/izlozbe/U\%20slu\%C5\%BEbi\%20arheologije,474. html) preuzeto 28.12. 2018.

- http://www.min-kulture.hr-(Registar kulturnih dobara), preuzeto 28.12.2018. 


\section{SAŽETAK \\ PREGLED ARHEOLOŠKIH ISTRAŽIVANJA POVIJESNE JEZGRE GRADA VARAŽDINA}

Jezgra grada Varaždina definira se kao prostor koji su do 19. st. omeđivali gradski opkopi i fortifikacije, zajedno s prostorom utvrde Stari grad. Arheološka istraživanja na ovom prostoru u radu je bilo moguće kronološki i prema intenzitetu izvođenja podijeliti u tri glavna razdoblja. Razdoblje prije i tokom Drugog svjetskog rata (Filićeva istraživanja), zatim razdoblje nakon Drugog svjetskog rata te razdoblje nakon 1993. god. Prvo razdoblje karakterizira vrijeme samih početaka iskopavanja (istraživanja) od 1938. god. do 1943. god. kada se na prostoru utvrde Stari grad, pod vodstvom Krešimira Filića, odvijaju iskopavanja zbog potrebe uređenja okoliša Starog grada. Sljedeće razdoblje, nakon Drugog svjetskog rata je, mogli bismo reći, vrijeme stagnacije arheoloških istraživanja u gradu te je obilježeno samo dvama većim arheološkim istraživanjima na prostoru grada, i to; istraživanjem tzv. Brvnare na današnjem Franjevačkom trgu 1954. god. i 1962./'63. god. sondiranjem u unutarnjem dvorištu utvrde Stari grad, pod vodstvom B. Vikić iz Arheološkog muzeja u Zagrebu. Ostalo su bila tek manja sondiranja utvrde, arhitektonskog karaktera 1970./'71. god. i sporadične zaštitne intervencije kustosa Gradskog muzeja Varaždin na lokacijama unutar grada; 1966. god. Kukuljevićeva ul., a 1984. god. i na prostoru Varteksove robne kuće u samom centru grada. U zadnjem razdoblju, od 1993. god., kada se događaju dva veća zaštitna arheološka iskopavanja u gradu (Blažekova ul. i križanje Šenoine ul. i Pavlinske ul.), dolazi do intenziviranja arheoloških nadzora i istraživanja, s dobrom pratećom dokumentacijom. Tako su do danas dokumentirane ukupno 24 lokacije istražene unutar grada, dok se prostor unutar areala utvrde Stari grad tokom ovog razdoblja istraživao u šest navrata. Također, tu su 2006. god. provedena i sustavna arheološka istraživanja, kao dio međunarodnog projekta nazvanog „Bastion“. Što se tiče konkretnih arheoloških podataka o gradu najviše su donijela istraživanja provedena upravo u ranije spomenutom projektu kada se došlo do podataka o sustavu fortifikacija oko Starog grada, ali i mnoštva nalaza datiranih od 15. do 20. st. Na većini lokacija u gradu koje su dosada istraživane su također pronađeni nalazi iz razdoblja kasnog srednjeg i novog vijeka, a na nekim lokacijama u gradu su pronađeni i dijelovi arhitekture (drvene i kamene) koji se mogu datirati u isti period, te fortifikacijski elementi grada - opkopi i zidovi. Jedini ranije datirani nalaz, koji nam sugerira da su se možda nekakve aktivnosti događale i u ranom srednjem vijeku u samom današnjem centru Varaždina, slučajni je nalaz franačkog koplja s krilcima, kod Lančane kule Starog grada. Zasada 
na prostoru jezgre grada nisu otkriveni nikakvi pokretni, ni nepokretni arheološki nalazi koji bi upućivali da se tu živjelo i prije srednjeg vijeka. Naravno, sve ovo samo je prikaz trenutnog stanja arheološke istraženosti grada Varaždina, te je podložno promjenama u budućnosti.

Ključne riječi: arheološka istraživanja; povijesna jezgra; gradska arheologija; grad Varaždin.

\section{SUMMARY}

\section{AN OWERVIEW OF ARCHAEOLOGICAL RESEARCHES IN THE CITY OF VARAŽDIN HISTORIC CORE}

The core of the city of Varaždin is defined as a space that was surrounded with town's graveyards and fortifications, by the 19th century, together with the site of the Old City fortress. Archaeological researches in this area were possible to divide into three main periods, in chronological order and in terms of performance intensity. The period before and during World War II (Filić's research), then the period after the World War II and the period after 1993 The first period is characterized by the very beginning of excavation, since 1938 until 1943 when in the territory of the fortress the Old Town, under the direction of Krešimir Filić, was excavated in the area, due to the need of landscaping around the Old Town. The next period after the World War II was the time of stagnation of archaeological research in the city and it was marked by only two major archaeological researches in the city's territory; research of the so-called Brvnara (log cabin) on today's Franciscan Square in 1954 and 1962/63 year, probe in the inner courtyard of the Old Town fortress, led by B. Vikić from the Zagreb Archaeological Museum. The rest were only minor probes around the fort, architectural character in $1970 / 71$ and sporadic rescue interventions of the curators of the Varaždin City Museum on locations within the city; in the 1966. Kukuljevićeva street, and in 1984 at the "Varteks" department store in the very center of the town. In the last period, since 1993, when two major archaeological excavations occur in the city (Blažekova street and corner of Šenoina street and Pavlinska street), archeological surveys and research intensified, with well supporting documentation. In that way, a total of 24 locations investigated within the city have been documented up to today, while the area within the territory of the fortress of the Old City during this period, was investigated on multiple archaeological probes, on 6 occasions. Also in the 2006 systematic archaeological research was conducted 
there, as part of an international project called "Bastion". In the above-mentioned project a lot of new data about the fortification system around the Old Town were collected, as well as a number of finds which dating from the 15th to the 20th century. If we compered it to the other finds which have been found in other archeological researches in the city they can be dated to the almost same period. The only surely dated finding that can be conected with some of the activities in the city during the early Middle Ages is a random find of a Frankish winged spear in front of the Lančana kula, entrance tower of the Old Town. In addition to the numerous movable findings from the late Middle Ages and Early Modern period at some locations of the city have been found parts of (wooden and stone) architecture that can be dated to the same period, but also fortification elements of diches and walls. For the time being, in the area of the core of the city of Varaždin haven't been found any movable or immobile archeological finds that would suggest that there were some settlement, before the Middle Ages. Of course all of this is just a reflection of the current state of archeological exploration of the city of Varaždin and can be changed in future researches.

Key Words: archeological researches; city of Varaždin; historical city core; urban archaeology. 